\title{
Deglaciation of a large piedmont lobe glacier in comparison with a small mountain glacier - new insight from surface exposure dating. Two studies from SE Germany
}

\author{
Anne U. Reuther, Markus Fiebig, Susan Ivy-Ochs, Peter W. Kubik, Jürgen M. Reitner, Hermann Jerz, Klaus Heine
}

Abstract:

\begin{abstract}
${ }^{10} \mathrm{Be}$ surface exposure ages of moraine boulders deposited during the maximum Würmian ice extent and the deglaciation period in two different glacial environments show different age distributions despite similar climatic boundary conditions. A consistent and precise late Würmian chronostratigraphy was derived from deposits of a small valley glacier in the Bavarian Forest. Exposure ages from terminal moraines of the Isar-Loisach and the Inn glacier in the Eastern Alps indicate a moraine deposition well before $18.0 \pm 1.9 \mathrm{ka}$ and moraine stabilization throughout the late glacial. Both glacial systems reached their maximum Würmian ice extent during the late Würmian. Despite this broad synchronicity, the response time to climatic fluctuations of the valley glacier in comparison to that of the piedmont glacier system is different, with the valley glacier being more sensitive to climatic signals. Synchronicity of the late glacial readvance in the Bavarian Forest and the Eastern Alps was reached during 16-15 ka (Gschnitz advance), when only valley glaciers existed in both regions. The age distributions determined for either of these glacial environments originate likely in glacier ice dynamics and geomorphic processes affecting moraine stabilization acting differently in each setting. Our data gives insight into landscape stability and moraine degradation in different glacial environments and has implications for sampling strategies and data interpretation for glacial exposure ages.
\end{abstract}

\section{[Deglaziation eines großen Vorlandgletschers im Vergleich mit einem kleinen Gebirgsgletscher - neue Erkenntnisse aufgrund von Oberflächenexpositionsaltern. Zwei Studien aus Südost-Deutschland]}

Kurzfassung:

\begin{abstract}
${ }^{10}$ Be-Oberflächenaltersdatierungen von Moränenblöcken der Würm-Maximalvergletscherung und der Deglaziationzeit ergaben in zwei verschiedenen Regionen Süddeutschlands unterschiedliche Altersverteilungen trotz gleicher klimatischer Randbedingungen. Im Bayerischen Wald zeigen die Moränenalter eines kleinen Talgletschers eine präzise und konsistente spätwürmzeitliche Chronostratigraphie. Oberflächenexpositionsalter von Moränen des Isar-Loisach und Inngletschers in den Ostalpen weisen auf eine hochwürmzeitliche Moränenablagerung deutlich vor 18.0 1.9 ka und einer anschliessenden Moränenstabilisierung hin. Beide glaziale Systeme (Mittelgebirgs-Talgletscher und alpines Eisstromnetz) erreichten ihre maximale Ausdehnung im Spätwürm (MIS 2). Trotz der weitgehenden Übereinstimmung war ihre Reaktionszeit auf Klimafluktuationen sehr unterschiedlich: der kleine Talgletscher reagierte empfindlicher auf klimatische Änderungen als das alpine Eisstromnetz. Ein synchrones Verhalten zeigten die Gletscher im Bayerischen Wald sowie in den Ostalpen erst im Spätglazial um 16-15 ka (H 1), als in beiden Gebieten Talgletscher existierten. Die unterschiedlichen Altersverteilungen der spätwürmzeitlichen Chronologien in den beiden Würmgletscher-Endmoränengebieten werden mit Unterschieden der Eisdynamik und der geomorphologischen Prozesse bei der Moränenstabilisierung sowie mit Phasen intensiver Hangprozesse infolge periglazialer Aktivität und ToteisTauens erklärt. Die Ergebnisse sind für Probennahmestrategien und Dateninterpretation von Moränen-Oberflächenaltern von großer Bedeutung.
\end{abstract}

Keywords: $\quad$ Bavarian Forest, Eastern Alps, Inn glacier, Isar-Loisach glacier, Würm type section, cosmogenic dating, moraine degradation, dead ice

Addresses of authors: A. U. Reuther, Department of Physical Geography, University of Regensburg, Germany. presently at: Cooperative Institute of Research in Environmental Sciences (CIRES) at University of Colorado, Boulder, USA. E-Mail: anne.u.gold@colorado.edu; M. Fiebig, University of Natural Resources and Applied Life Sciences, Vienna, Austria. E-Mail: markus.fiebig@boku.ac.at; S. Ivy-Ochs, Department of Geography, University of Zurich, and Laboratory of Ion Beam Physics, ETH Zuerich, Zurich, Switzerland. E-Mail: ivy@phys.ethz.ch; P. W. Kubik, Laboratory of Ion Beam Physics, ETH Zuerich, Zurich, Switzerland. E-Mail: kubik@ phys.ethz.ch; J. M. Reitner, Geological Survey of Austria, Vienna, Austria. E-Mail: juergen.reitner@geologie.ac.at; H. Jerz, University of Augsburg, Germany. presently: Eichleite 7, 82031 Grünwald, Germany. E-Mail: hjerz@yahoo.de; K. Heine, Department of Geography, University of Regensburg, 93040 Regensburg, Germany. E-Mail: klaus.heine@geographie.uni-regensburg.de

\section{Introduction}

Glacial landscapes are one of the classical study areas for surface exposure dating with terrestrial in-situ produced cosmogenic nuclides (TCND) (Phillips et al. 1990; Gosse et al. 1995a, b; CockBurn \& Summerfield 2004). The method is frequently applied to constrain glacial chronologies based on exposure ages of moraine boulders (REuTHER et al. 2006). However, the age distributions that are determined in moraine dating studies do not always reflect the landform age (Reuther et al. 2006, Heine, 2011). The scatter that is found in these datasets is often greater than statistically expected from the associated errors and frequently biased or polymodal age distributions are determined (PutKonen \& SwANson 2003). This scatter is likely explained by geomorphological processes such as for example multiple glacial advances or post-depositional degradation of moraines (ZREDA et al. 1994; BRINER et al. 2005; Zech et al. 2005; PutKonen \& O’NeAl 2006). In glacial environments the assumptions underlying the TCND technique are often not valid because (1) moraines that contain dead ice or that are exposed to intensive periglacial slope 


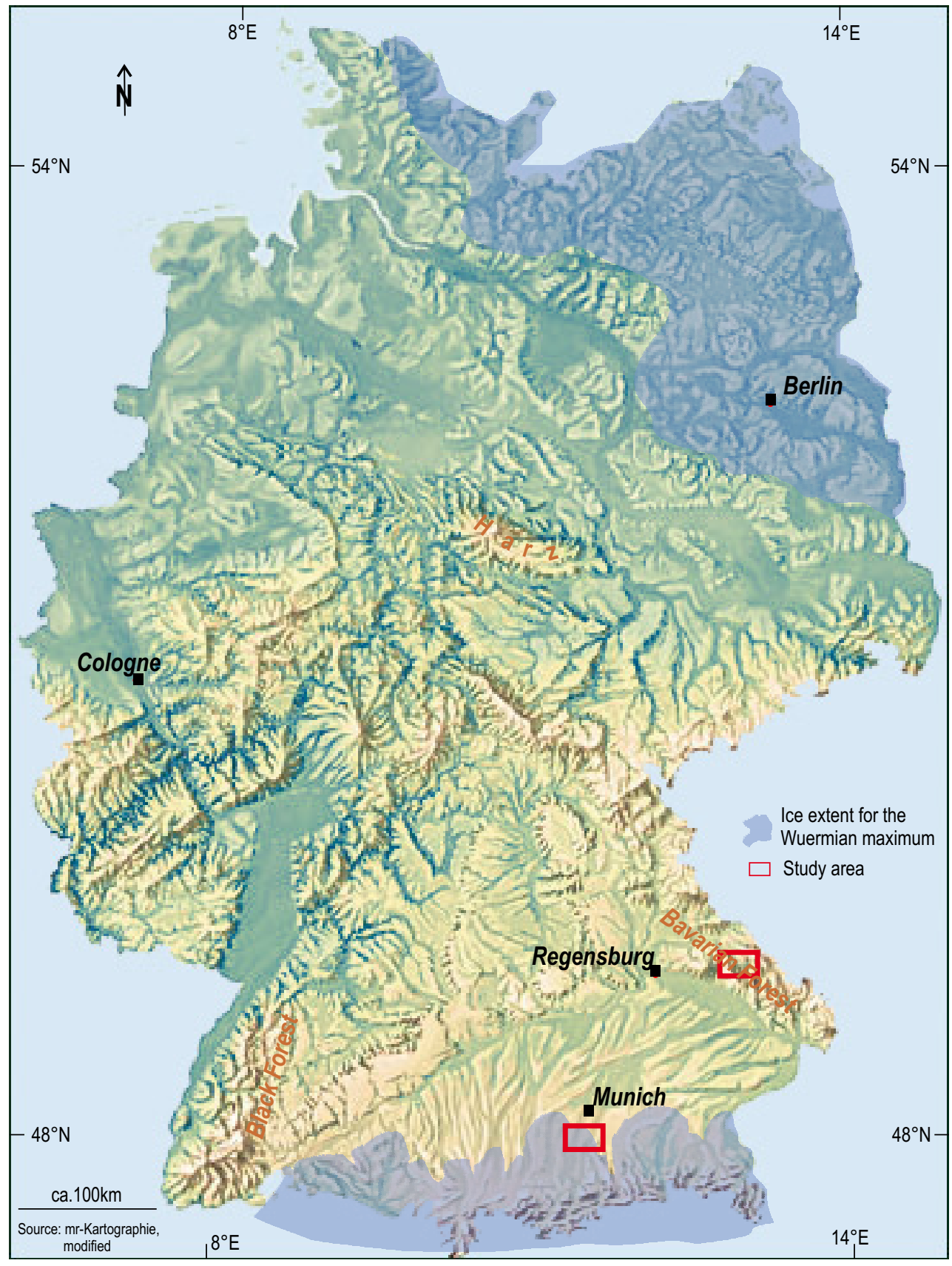

Fig. 1: Shaded relief of Germany showing the late Weichselian/Würmian ice extent and the periglacial corridor between the two ice masses. Study areas are marked with red boxes.

Abb. 1: Reliefdarstellung der spätWeichsel/Würm-zeitlichen Eisausdehnung in Deutschland und des periglazialen Korridors zwischen den beiden Eismassen. Die Untersuchungsgebiete sind jeweils mit einem roten Kasten markiert. processes are unstable landforms at the timescales of $10^{2}$ to $10^{3}$ years and (2) moraine boulders do sometimes carry inherited nuclide abundance. In these cases non-Gaussian exposure age distributions are determined from moraine boulders. Furthermore, the glacier type (e.g. valley glaciation or continental ice sheets; warm-based or cold-based) and the climatic boundary conditions (arid or humid; tropical or arctic) influence moraine stability or degradation and thus the exposure age distributions from moraine boulders (EvANS 2004).

Models of moraine degradation or boulder exhumation have been published that help understanding and quantifying the principles of surface processes (ZREDA et al. 1994; Hallet \& Putkonen 1994; Zreda \& Phillips 1995; Putkonen \& Swanson 2003). However, the depositional environment of each moraine boulder and the climatic boundary conditions that affected the moraine during and after deposition have not yet been incorporated in the mod- els but need to be considered in the data interpretation.

In any glacial environment, exposure ages from boulders on moraines will yield the time of landform stabilization; the probability of inherited nuclide concentration is only a few percent (PutKonen \& SwANSon 2003). A valley glacier with negligible debris cover often leaves behind simple, well preserved moraine sequences (Heim 1885). In contrast, at the ice margin of extensive ice lobes, dead ice bodies are often disconnected from the active glacier during deglaciation. These debris-covered dead ice bodies or ice-cored moraines will persist until climatic conditions are favourable enough for their thawing causing intensive moraine degradation (GRIPP \& EBERS 1957; Dyke \& SAVELle 2000; Everest \& BRADWELl 2003).

In this study we exposure dated moraine boulders in different glacial environments (piedmont shaped outlet lobes from central Alpine ice caps versus small valley glacier system in the Bavarian Forest) that were affected by similar 
climatic boundary conditions during the late Pleistocene. This research setup allows testing the hypothesis of variations in exposure age distributions on moraines due to different glacial environments. Central Europe is an ideal study area to address this research question, as different glacial environments can be found in close proximity.

During the Würmian last glacial maximum the central European climatic regime was strongly influenced by the large Scandinavian ice sheet extending far into Northern Germany (EHLERs et al. 2004; HeINe et al. 2009) as well as the Alpine ice cap with its extensive ice domes, its inneralpine network of large interconnected valley glaciers and outlet glaciers that spread out as extensive piedmont lobes onto the Alpine foreland (PENCK \& BRÜCKNER 1901/09; van Husen 1997; Florineth \& SChlüchter 1998; Kelly et al. 2004). A $500 \mathrm{~km}$ wide periglacial corridor extended between these two large ice masses (Fig. 1). Only a few isolated mountain ranges carried small mountain glaciers, as for instance the Black Forest, the Vosges, the Bavarian Forest and the Harz Mountains (Fig. 1; SERET et al. 1990; ROTHER 1995).

Numerous chronological studies have bracketed the timing of glacial advances in the Alps and in the area covered by the Scandinavian ice sheet, indicating that both large ice masses reached their last glacial maximum ice extent coeval during the late Würmian, respectively late Weichselian (e.g. EHLERs \& GibBARD 2004a). Terrestrial glacial chronologies for low mountainous areas of central Europe (Mittelgebirge) are still patchy and no coherent numerical glacial chronology for any of the mountain ranges has yet been established (e.g. Rother 1995). Cosmogenic ages of moraines will considerably advance the age control of glaciations as the method allows direct dating of glacial deposition and thus supplements the bracketing radiocarbon ages.

As study sites we chose the respective type sections of the Eastern Alpine piedmont glaciation and the small mountain glaciation in the Bavarian Forest in south-eastern Germany. The Bavarian Forest is located only some 160 $\mathrm{km}$ north/northeast of the terminal moraines of the Alpine piedmont glaciers (Fig 1).

In the Eastern Alps, a type section of the Würmian glaciation is the sequence of glacial deposits around the Würmsee (now called Starnberger See) deposited by the former Isar-Loisach glacier (CHALINE \& JERZ 1984). This sequence of glacial deposits was eponymous for the Würm glaciation (PENCK \& BRÜCKNER 1901/09) and has been intensively mapped and studied (e.g. PENCK \& BRÜCKNER 1901/09; Troll 1937; Rothpletz 1917; Jerz 1987a, b; Feldmann 1992). Up to now, no numerical ages constrain the chronology of these glacial deposits.

The glacial sequence around the Kleiner Arbersee is typical for the late Würmian glaciation in the Bavarian Forest (PARTSCh 1882; Penck et al. 1887; Jerz 1993). The deposits of this sequence are well mapped (BAYBERGER 1886; Rathsburg 1928, 1930; Priehäusser 1927, 1930; Bucher 1999) and have been sedimentologically studied in detail (HAuner 1980; MAHr 1998; RAAB 1999; RAAB \& VölKel 2003). However, only a few radiocarbon dates yield minimum ages for the regional deglaciation (RAAB \& VÖLKEL 2003).
The goal of our study was two-fold: Firstly, we aimed to establish a numerical chronology for the Würmian glaciation at the respective type localities in the Eastern Alps and the Bavarian Forest mountain range which are numerically undated sites, and secondly, we aimed to compare the validity of surface exposure dating in two very different glacial settings (Alpine piedmont glacier on foreland versus small valley glacier system in Bavarian Forest).

In the first part of this paper the results from the numerical dating studies for both field areas are presented. In the second part the implications of our studies for surface exposure dating in different glacial settings are discussed.

\section{Materials and Methods}

19 boulder and bedrock samples were taken in the Bavarian Forest from gneiss surfaces. 10 crystalline boulder surfaces were sampled on the Alpine foreland moraines. Geographic coordinates and topographic shielding were measured using a GPS receiver and a hand-held inclinometer, respectively (Tab. 1, 2).

The samples were crushed and ground and the quartz fraction was separated following the procedures described by Kohl \& Nishizzumi (1992) and Ivy-Ochs (1996). BeO was extracted using a combination of column chemistry separation and selective hydroxide precipitations (OcHs \& Ivy-Ochs 1997). Ratios of the radionuclide to the stable nuclide were measured using accelerator mass spectrometry (AMS) at the ETH Zurich tandem accelerator facility (SynAL et al. 1997). Apparent exposure ages were calculated from the measured nuclide concentration, the sitespecific production rate according to LAL (1991) and STONE (2000) and the sampling depth. They were corrected for topographic shielding (DUNNE et al. 1999), variations in the geomagnetic field (LAJ et al. 2004), erosion, uplift, snow and vegetation cover (Gosse \& PHILlips 2001). The dense forest canopy inhibited field measurements of the topographic shielding in the Bavarian Forest. Shielding angles for each sample were calculated with a Geographic Information System (GIS) based on spatial information obtained from a high-resolution DEM (REuther 2007). The following aspects were considered for the corrections:

Bavarian Forest:

(i) The exposure ages were calculated using an erosion rate of $5 \pm 2 \mathrm{~mm} \mathrm{ka}^{-1}$ based on measurements in the field, a value that is in agreement with values used in similar studies (appendix 1).

(ii) Snow cover is significant (Fig. 2). At the Arber summit, a close snow cover is reported for 150-170 days $\mathrm{yr}^{-1}$ (Müller-Hohenstein 1973; HAuner 1980; Scheuerer 1997). In the sheltered cirques the snow melts considerably later than in more exposed locations. South of the Kleiner Arbersee (Seeloch) it persists until May or even June (BAumgartner 1970; Scheuerer 1997). For the age calculation an estimate of $30 \mathrm{~cm}$ snow cover for six months is assumed for the horizontal surfaces.

(iii) The Arber region is a densely forested area (Fig. 2). Several tree storeys occur and a moss and shrub cover grows on some bedrock surfaces. Some of the sampled surfaces were covered with a thin moss and humus layer. For the age calculation the mean of the reported biomass values of 

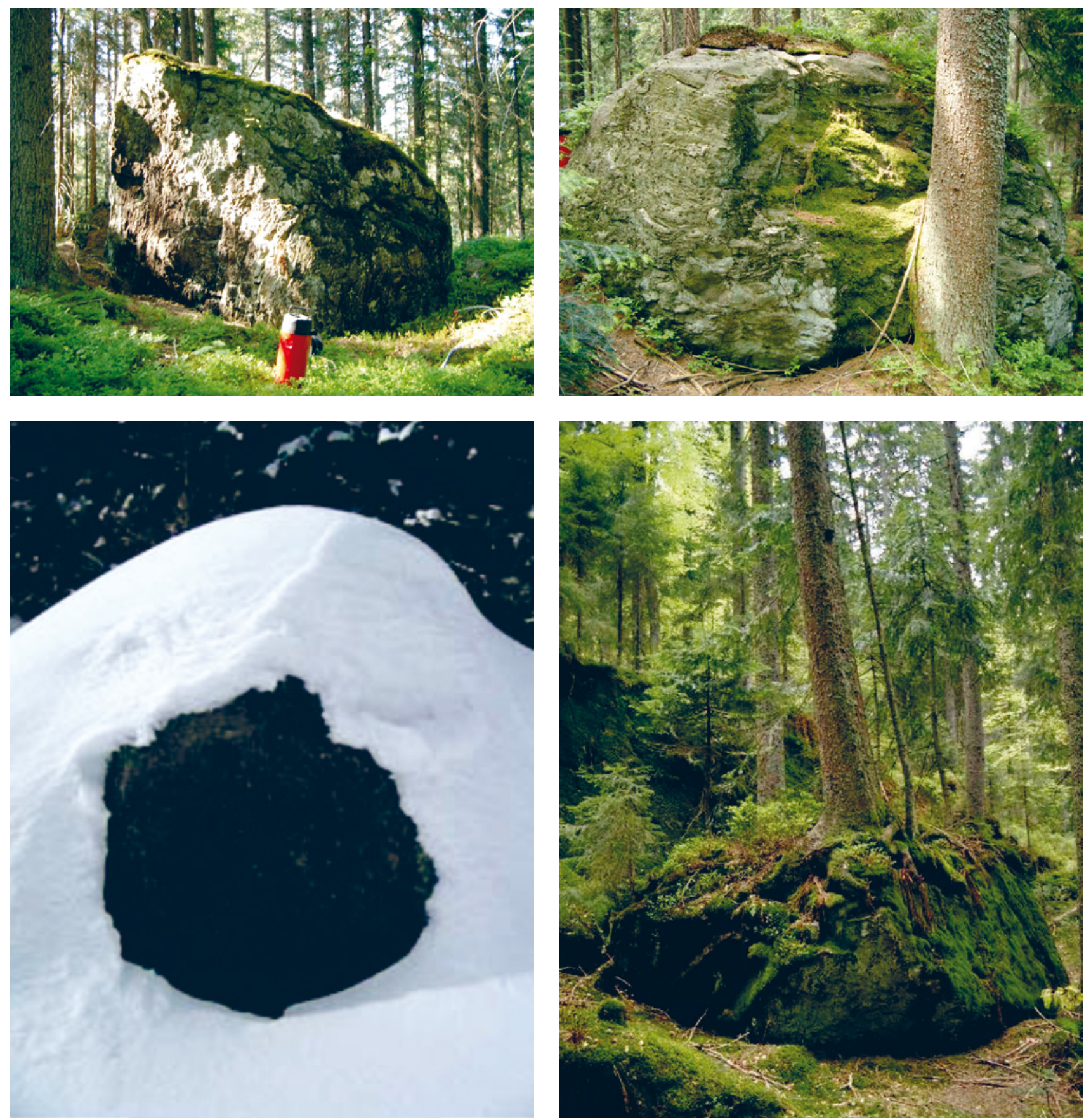

Fig. 2: Field photographs from the Bavarian Forest. Upper left is boulder BW-03-02, upper right is boulder BW-03-15, lower left shows the snow cover on top of boulders in the snow-rich winter of 2004, lower right shows the vegetation cover on some of the boulders. If the tree that is growing on the boulder falls over it is likely to topple the boulder (this boulder was not sampled).

Abb. 2: Geländeaufnahmen aus dem Bayerischen Wald. Oben links: Moränenblock BW-03-02, oben rechts: Moränenblock BW-03-15, unten links: Schneebedeckung auf einem Moränenblock im schneereichen Winter 2004, unten rechts: Vegetationsbedeckung auf Moränenblöcken. Wenn der Baum, der auf dem Moränenblock wächst, umfällt, wird der Block voraussichtlich gedreht (der Moränenblock wurde nicht beprobt).

spruce forests in Bavaria was assumed $\left(360 \mathrm{t} \mathrm{ha}^{-1}\right.$ for cultivated forests, Dietrich et al. 2002). This does neither comprises understorey vegetation nor humus cover. Forest cover of the study area is assumed for the last $10 \mathrm{ka}$. Radiocarbon dated pollen diagrams from the Kleiner Arbersee indicate that the first arboreal pollen occurred around 13.9-15.0 cal ka BP $\left(12,311 \pm 372{ }^{14} \mathrm{C}\right.$ yr BP; Raab 1999), indicating that the area was already forested around this time.

(iv) A (negative) vertical movement of the Bavarian Forest of 0 to $-0.9 \mathrm{~mm} \mathrm{yr}^{-1}$ has been measured (station Wettzell, T. KLÜGEL, pers. comm. 2005). For the correction of the pro- duction rate calculation a value of $-0.5 \mathrm{~mm} \mathrm{yr}^{-1}$ was estimated for the exposure duration.

\section{Alpine Foreland:}

(i) The exposure ages were calculated using an erosion rate of $5.5 \pm 2 \mathrm{~mm} \mathrm{ka}^{-1}$ based on field observations and measurements (appendix 1).

(ii) For snow cover corrections, the average snow depth $(20 \mathrm{~cm})$ and density $\left(0.3 \mathrm{~g} \mathrm{~cm}^{-3}\right)$ for about 4 months per year as measured at a near-by site (ATTMANNSPACHER 1981) are used in the calculations. 
Tab. 1: Exposure ages determined on moraines of the Kleiner Arbersee glacier, Bavarian Forest.

Tab. 1: Expositionsalter von Moränen des Kleiner Arbersee-Gletschers, Bayerischer Wald.

\begin{tabular}{|c|c|c|c|c|c|c|c|c|c|c|c|c|}
\hline Sample ID & $\begin{array}{l}\text { Lat / } \\
\text { Long }\end{array}$ & Altitude & \begin{tabular}{|l|} 
Height \\
above \\
ground, \\
base plane \\
area
\end{tabular} & $\begin{array}{l}\text { Sample } \\
\text { thick- } \\
\text { ness }\end{array}$ & \begin{tabular}{|l|}
$\mathbf{f}_{\text {corr }}$ \\
[topo, \\
slope]*
\end{tabular} & $\begin{array}{l}f_{\text {corr }} \\
\text { [veg, } \\
\text { snow]* }\end{array}$ & $\begin{array}{l}f_{\text {corr }} \\
\text { [geo- } \\
\text { mag] }\end{array}$ & $\begin{array}{l}{ }^{10} \mathrm{Be} \\
\text { atomt }\end{array}$ & $\begin{array}{l}\text { AMS } \\
\text { error }\end{array}$ & $\begin{array}{l}\text { Production } \\
\text { rate§ }\end{array}$ & $\begin{array}{l}\text { Apparent } \\
\text { age\# }\end{array}$ & $\begin{array}{l}\text { Exposure } \\
\text { age** }\end{array}$ \\
\hline & {$\left[{ }^{\circ}\right]$} & [m asl] & & {$[\mathrm{cm}]$} & & & & $\begin{array}{l}{\left[\mathrm{g}^{-1} \mathrm{SiO}_{2}^{-}\right.} \\
\left.1 * 10^{5}\right]\end{array}$ & [\%] & {$\left[\operatorname{atm~g} \mathrm{g}^{-1} \mathrm{yr}^{-1}\right]$} & {$\left[{ }^{10} \mathrm{Be} \mathrm{ka}\right]$} & {$\left[{ }^{10} \mathrm{Be} \mathrm{ka}\right]$} \\
\hline \multicolumn{13}{|c|}{ Wla - moraine } \\
\hline BW-03-15 & \begin{tabular}{|l|l|}
$49.13^{\circ} \mathrm{N}$ \\
$13.12^{\circ} \mathrm{E}$ \\
\end{tabular} & 862 & \begin{tabular}{|l|}
$1.1 \mathrm{~m}^{2}$ \\
$4.6 \mathrm{~m}^{2}$ \\
\end{tabular} & 3.5 & 0.997 & 0.965 & 1 & 2.09 & 3.3 & 10.5 & 19,508 & \begin{tabular}{|l}
$20.7 \pm 2.1$ \\
{$[ \pm 0.6]$} \\
\end{tabular} \\
\hline BW-03-14 & $\begin{array}{l}49.13^{\circ} \mathrm{N} \\
13.12^{\circ} \mathrm{E}\end{array}$ & 848 & $\begin{array}{l}0.9 \mathrm{~m} \\
2.6 \mathrm{~m}^{2}\end{array}$ & 4 & 0.997 & 0.964 & 1 & 1.83 & 6.8 & 10.2 & 17,379 & \begin{tabular}{|l}
$18.4 \pm 2.1$ \\
{$[ \pm 1.1]$}
\end{tabular} \\
\hline BW-03-16 & $\begin{array}{l}49.13^{\circ} \mathrm{N} \\
13.12^{\circ} \mathrm{E} \\
\end{array}$ & 874 & $\begin{array}{l}1.4 \mathrm{~m} \\
13.2 \mathrm{~m}^{2} \\
\end{array}$ & 4 & 0.997 & 0.964 & 1 & 1.95 & 3.4 & 10.5 & 18,024 & $\begin{array}{l}19.2 \pm 1.9 \\
{[ \pm 0.5]}\end{array}$ \\
\hline \multicolumn{13}{|c|}{ Wlb - moraine } \\
\hline BW-03-06 & \begin{tabular}{|l|l|}
$49.13^{\circ} \mathrm{N}$ \\
$13.12^{\circ} \mathrm{E}$ \\
\end{tabular} & 873 & \begin{tabular}{|l|}
$1.3 \mathrm{~m}$ \\
$10.5 \mathrm{~m}^{2}$ \\
\end{tabular} & 4.5 & 0.997 & 0.964 & 1 & 1.90 & 4.3 & 10.4 & 17,640 & \begin{tabular}{|l|}
$18.7 \pm 1.9$ \\
{$[ \pm 0.7]$}
\end{tabular} \\
\hline BW-03-02 & $\begin{array}{l}49.13^{\circ} \mathrm{N} \\
13.12^{\circ} \mathrm{E}\end{array}$ & 864 & $3 \mathrm{~m}$ & 4.5 & 0.996 & 0.964 & 1 & 1.88 & 4.1 & 10.3 & 17,649 & $\begin{array}{l}18.7 \pm 1.9 \\
{[ \pm 0.7]}\end{array}$ \\
\hline \multicolumn{13}{|c|}{ WI lateral moraine before it splits into Wla and WIb } \\
\hline BW-03-07 & \begin{tabular}{|l|l|}
$49.13^{\circ} \mathrm{N}$ \\
$13.12^{\circ} \mathrm{E}$ \\
\end{tabular} & 860 & \begin{tabular}{|l|}
$2 \mathrm{~m}$ \\
$4.5 \mathrm{~m}^{2}$ \\
\end{tabular} & 4.5 & 0.995 & 0.963 & 1 & 1.69 & 4.5 & 10.3 & 15,951 & $\begin{array}{l}16.9 \pm 1.8 \\
{[ \pm 0.7]} \\
\end{array}$ \\
\hline BW-03-08 & \begin{tabular}{|l|l|}
$49.13^{\circ} \mathrm{N}$ \\
$13.12^{\circ} \mathrm{E}$ \\
\end{tabular} & 936 & $\begin{array}{l}1.3 \mathrm{~m} \\
5.3 \mathrm{~m}^{2} \\
\end{array}$ & 3.5 & 0.996 & 0.964 & 1 & 2.03 & 3.6 & 11.1 & 17,775 & $\begin{array}{l}18.8 \pm 1.9 \\
{[ \pm 0.6]} \\
\end{array}$ \\
\hline BW-03-17 & $\begin{array}{l}49.13^{\circ} \mathrm{N} \\
13.12^{\circ} \mathrm{E}\end{array}$ & 892 & $\begin{array}{l}1.8 \mathrm{~m} \\
7.35 \mathrm{~m}^{2}\end{array}$ & 5 & 0.997 & 0.962 & 0.99 & 1.63 & 7.5 & 10.5 & 14,973 & $\begin{array}{l}15.9 \pm 1.9 \\
{[ \pm 1.0]}\end{array}$ \\
\hline BW-03-18 & \begin{tabular}{|l|}
$49.13^{\circ} \mathrm{N}$ \\
$13.12^{\circ} \mathrm{E}$ \\
\end{tabular} & 893 & $\begin{array}{l}0.9 \mathrm{~m} \\
5.2 \mathrm{~m}^{2} \\
\end{array}$ & 4.5 & 0.996 & 0.961 & 0.99 & 1.54 & 6.0 & 10.5 & 14,090 & $\begin{array}{l}15.0 \pm 1.7 \\
{[ \pm 0.8]}\end{array}$ \\
\hline BW-03-19 & $\begin{array}{l}49.13^{\circ} \mathrm{N} \\
13.12^{\circ} \mathrm{E} \\
\end{array}$ & 898 & $\begin{array}{l}1.4 \mathrm{~m}^{2} \\
5.1 \mathrm{~m}^{2} \\
\end{array}$ & 4.5 & 0.994 & 0.963 & 1 & 1.79 & 3.5 & 10.6 & 16,396 & $\begin{array}{l}17.4 \pm 1.8 \\
{[ \pm 0.5]}\end{array}$ \\
\hline \multicolumn{13}{|l|}{ WII moraine } \\
\hline BW-03-03 & \begin{tabular}{|l|}
$49.13^{\circ} \mathrm{N}$ \\
$13.12^{\circ} \mathrm{E}$ \\
\end{tabular} & 870 & \begin{tabular}{|l|}
$1.5 \mathrm{~m}$ \\
$2.4 \mathrm{~m}^{2}$ \\
\end{tabular} & 4 & 0.996 & 0.963 & 0.99 & 1.76 & 4.0 & 10.4 & 16,364 & \begin{tabular}{|l|}
$17.4 \pm 1.8$ \\
{$[ \pm 0.6]$} \\
\end{tabular} \\
\hline Bw-03-04 & \begin{tabular}{|l|}
$49.13^{\circ} \mathrm{N}$ \\
$13.12^{\circ} \mathrm{E}$ \\
\end{tabular} & 871 & \begin{tabular}{|l|}
$1.1 \mathrm{~m}$ \\
$6 \mathrm{~m}^{2}$ \\
\end{tabular} & 6.1 & 0.996 & 0.961 & 0.99 & 1.53 & 4.9 & 10.2 & 14,472 & \begin{tabular}{|l|}
$15.4 \pm 1.7$ \\
{$[ \pm 0.6]$} \\
\end{tabular} \\
\hline BW-03-20 & \begin{tabular}{|l|}
$49.13^{\circ} \mathrm{N}$ \\
$13.12^{\circ} \mathrm{E}$ \\
\end{tabular} & 870 & \begin{tabular}{|l|}
$1.2 \mathrm{~m}$ \\
$1.4 \mathrm{~m}^{2}$ \\
\end{tabular} & 4.5 & 0.995 & 0.963 & 1 & 1.74 & 3.7 & 10.4 & 16,243 & $\begin{array}{l}17.2 \pm 1.8 \\
{[ \pm 0.5]}\end{array}$ \\
\hline \multicolumn{13}{|c|}{ Lake moraine } \\
\hline BW-04-03 & \begin{tabular}{|l|l|}
$49.13^{\circ} \mathrm{N}$ \\
$13.12^{\circ} \mathrm{E}$ \\
\end{tabular} & 905 & \begin{tabular}{|l|}
$2 \mathrm{~m}$ \\
$12 \mathrm{~m}^{2}$ \\
\end{tabular} & 3.5 & 0.996 & 0.962 & 1 & 1.66 & 4.5 & 10.7 & 14,894 & \begin{tabular}{|l|}
$15.8 \pm 1.7$ \\
{$[ \pm 0.6]$}
\end{tabular} \\
\hline BW-04-04 & $\begin{array}{l}49.13^{\circ} \mathrm{N} \\
13.12^{\circ} \mathrm{E}\end{array}$ & 915 & \begin{tabular}{|l|}
$3.2 \mathrm{~m}$ \\
$10.5 \mathrm{~m}^{2}$ \\
\end{tabular} & 3.5 & 0.996 & 0.962 & 1 & 1.68 & 9.9 & 10.8 & 14,992 & $\begin{array}{l}15.9 \pm 2.1 \\
{[ \pm 1.4]}\end{array}$ \\
\hline BW-03-09 & $\begin{array}{l}49.13^{\circ} \mathrm{N} \\
13.12^{\circ} \mathrm{E} \\
\end{array}$ & 945 & $\begin{array}{l}1.5 \mathrm{~m} \\
6.4 \mathrm{~m}^{2} \\
\end{array}$ & 4 & 0.997 & 0.961 & 0.99 & 1.61 & 4.1 & 11.0 & 14,092 & $\begin{array}{l}15.0 \pm 1.6 \\
{[ \pm 0.5]}\end{array}$ \\
\hline \multicolumn{13}{|c|}{ Bedrock surface south of lake } \\
\hline KAS-1-1 & \begin{tabular}{|l|}
$49.13^{\circ} \mathrm{N}$ \\
$13.12^{\circ} \mathrm{E}$ \\
\end{tabular} & 935 & bedrock & $0.85-1$ & 0.655 & 1.000 & 0.99 & 1.06 & 6 & 7.6 & 13,839 & \begin{tabular}{|l|}
$14.0 \pm 1.7$ \\
{$[ \pm 0.5]$} \\
\end{tabular} \\
\hline KAS-2-1 & $\begin{array}{l}49.13^{\circ} \mathrm{N} \\
13.12^{\circ} \mathrm{E} \\
\end{array}$ & 935 & bedrock & $0.85-1$ & 0.655 & 1.000 & 0.99 & 1.11 & 4.2 & 7.7 & 14,470 & $\begin{array}{l}14.6 \pm 1.8 \\
{[ \pm 0.6]}\end{array}$ \\
\hline KAS-3-1 & $\begin{array}{l}49.13^{\circ} \mathrm{N} \\
13.12^{\circ} \mathrm{E}\end{array}$ & 935 & bedrock & $0.85-1$ & 0.622 & 1.000 & 0.99 & 1.03 & 5.3 & 7.3 & 14,038 & $\begin{array}{l}14.2 \pm 1.8 \\
{[ \pm 0.7]}\end{array}$ \\
\hline \multicolumn{13}{|c|}{ Bedrock surface on summit [reference to this data in appendix] } \\
\hline BW-04-01 & $\begin{array}{l}49.11^{\circ} \mathrm{N} \\
13.13^{\circ} \mathrm{N}\end{array}$ & 1,350 & bedrock & 4.5 & 0.997 & 0.977 & 1 & $\begin{array}{l}6.2 \\
6.2\end{array}$ & 15.9 & $\begin{array}{r}102.432 \\
94.424\end{array}$ & \begin{tabular}{|l} 
Erosion \\
rate
\end{tabular} & \begin{tabular}{|l} 
Erosion \\
rate
\end{tabular} \\
\hline
\end{tabular}

Note: Samples were processed and measured at ETH Zurich tandem facility. The ${ }^{10} \mathrm{Be}$ concentrations and exposure ages are based on AMS standard S555 with a nominal value of $95.5 \mathrm{E}-12$ and an associated ${ }^{10} \mathrm{Be}$ half-life of $1.51 \mathrm{Ma}$.

* correction factor for the effect of topographic shielding and surface geometry [exponential depth profile, nucleonic attenuation length $155 \mathrm{~g}$ $\mathrm{cm}^{-2}$, muonic attenuation length $1510 \mathrm{~g} \mathrm{~cm}^{-2}$, coefficient $\mathrm{m}=2.3$ for the nucleonic and $\mathrm{m}=2.1$ for the muonic component].

$\uparrow$ blank-corrected.

$\S$ local production rate corrected for geometry, topography, sample thickness, erosion, snow cover, uplift and geomagnetic variations.

\# corrected only for topographic shielding, geometry and sample thickness.

** exposure age corrected for all mentioned factors [section 3], error give the 1- $\sigma$ uncertainty including analytical and systematic errors to be used when quoting absolute exposure age of boulder; errors in parenthesis give only the analytical uncertainty for comparison of different boulders in the same area. 
Tab. 2: Exposure ages determined on terminal moraine complex of the Isar-Loisach glacier, Alpine Foreland and from glacial deposits of the Inn glacier. Tab. 2: Expositionsalter der Endmoränen des Isar-Loisach-Gletschers, Alpenvorland, und von glazialen Ablagerungen des Inn-Gletschers.

\begin{tabular}{|c|c|c|c|c|c|c|c|c|c|c|c|c|}
\hline Sample ID & $\begin{array}{l}\text { Lat / } \\
\text { Long }\end{array}$ & Altitude & $\begin{array}{l}\text { Height } \\
\text { above } \\
\text { ground, } \\
\text { base pla- } \\
\text { ne area }\end{array}$ & $\begin{array}{l}\text { Sample } \\
\text { thickness }\end{array}$ & $\begin{array}{l}\mathbf{f}_{\text {corr }} \\
\text { [topo, } \\
\text { slope]* }\end{array}$ & $\begin{array}{l}\mathbf{f}_{\text {corr }} \\
\text { [veg, } \\
\text { snow]* }\end{array}$ & $\begin{array}{l}f_{\text {corr }} \\
\text { [geo- } \\
\text { mag] }\end{array}$ & $\begin{array}{l}{ }^{10} \mathrm{Be} \\
\text { atomt }\end{array}$ & $\begin{array}{l}\text { AMS } \\
\text { error }\end{array}$ & $\begin{array}{l}\text { Production } \\
\text { rateS }\end{array}$ & $\begin{array}{l}\text { Apparent } \\
\text { age\# }\end{array}$ & $\begin{array}{l}\text { Exposure } \\
\text { age** }\end{array}$ \\
\hline & {$\left[{ }^{\circ}\right]$} & {$[\mathrm{m}$ asl $]$} & & {$[\mathrm{cm}]$} & & & & $\begin{array}{l}{\left[\mathrm{g}^{-1} \mathrm{SiO}_{2}^{-1}\right.} \\
\left.* 10^{5}\right] \\
\end{array}$ & {$[\%]$} & {$\left[\right.$ atm g $\left.\mathrm{g}^{-1} \mathrm{yr}^{-1}\right]$} & {$\left[{ }^{10} \mathrm{Be} \mathrm{ka}\right]$} & {$\left[{ }^{10} \mathrm{Be} \mathrm{ka}\right]$} \\
\hline \multicolumn{13}{|c|}{ Maximum terminal moraine } \\
\hline AVS-03-01 & $\begin{array}{l}47.98^{\circ} \mathrm{N} \\
11.42^{\circ} \mathrm{E} \\
\end{array}$ & 670 & $\begin{array}{l}1.1 \mathrm{~m} \\
5.4 \mathrm{~m}^{2}\end{array}$ & 5.6 & 0.997 & 0.974 & 1.00 & 1.5 & 5.2 & 8.6 & 16,891 & $\begin{array}{l}18.0 \pm 1.9 \\
{[ \pm 0.8]}\end{array}$ \\
\hline AVS-03-05 & $\begin{array}{l}47.99^{\circ} \mathrm{N} \\
11.40^{\circ} \mathrm{E} \\
\end{array}$ & 645 & $\begin{array}{l}1 \mathrm{~m} \\
11.2 \mathrm{~m}^{2}\end{array}$ & 4.5 & 1 & 0.981 & 1.01 & 3.24 & 3.0 & 8.6 & 37,038 & $\begin{array}{l}40.4 \pm 3.1 \\
{[ \pm 0.8]}\end{array}$ \\
\hline AVS-03-06 & $\begin{array}{l}47.99^{\circ} \mathrm{N} \\
11.40^{\circ} \mathrm{E} \\
\end{array}$ & 650 & $\begin{array}{l}1 \mathrm{~m} \\
3.6 \mathrm{~m}^{2}\end{array}$ & 5 & 1 & 0.973 & 1.00 & 1.37 & 5.6 & 8.5 & 15,579 & $\begin{array}{l}16.6 \pm 1.8 \\
{[ \pm 0.8]}\end{array}$ \\
\hline AVS-03-10 & $\begin{array}{l}48.02^{\circ} \mathrm{N} \\
11.40^{\circ} \mathrm{E} \\
\end{array}$ & 650 & $\begin{array}{l}1.1 \mathrm{~m} \\
5.9 \mathrm{~m}^{2}\end{array}$ & 4.5 & 0.999 & 0.967 & 0.99 & 1.0 & 5.0 & 8.4 & 11,346 & $\begin{array}{l}12.1 \pm 1.4 \\
{[ \pm 0.5]}\end{array}$ \\
\hline AVS-03-11 & $\begin{array}{l}48.02^{\circ} \mathrm{N} \\
11.40^{\circ} \mathrm{E}\end{array}$ & 655 & $\begin{array}{l}1.1 \mathrm{~m} \\
4.2 \mathrm{~m}^{2}\end{array}$ & 5 & 0.987 & 0.971 & 1.00 & 1.25 & 5.6 & 8.4 & 14,352 & $\begin{array}{l}15.3 \pm 1.7 \\
{[ \pm 0.7]}\end{array}$ \\
\hline AVS-03-22 & $\begin{array}{l}47.99^{\circ} \mathrm{N} \\
11.40^{\circ} \mathrm{E} \\
\end{array}$ & 685 & $\begin{array}{l}1.2 \mathrm{~m} \\
4.5 \mathrm{~m}^{2}\end{array}$ & 5.5 & 0.994 & 0.972 & 1.00 & 1.3 & 5.7 & 8.6 & 14,513 & $\begin{array}{l}15.5 \pm 1.7 \\
{[ \pm 0.8]}\end{array}$ \\
\hline \multicolumn{13}{|c|}{ Moraine arch ice-proximal to terminal moraine } \\
\hline AVS-03-03 & $\begin{array}{l}48.00^{\circ} \mathrm{N} \\
11.39^{\circ} \mathrm{E}\end{array}$ & 656 & $\begin{array}{l}0.8 \mathrm{~m} \\
2.9 \mathrm{~m}^{2}\end{array}$ & 5.5 & 0.997 & 0.974 & 1.00 & 1.47 & 4.5 & 8.5 & 16,661 & $\begin{array}{l}17.9 \pm 1.9 \\
{[ \pm 0.7]}\end{array}$ \\
\hline AVS-03-04 & $\begin{array}{l}47.95^{\circ} \mathrm{N} \\
11.39^{\circ} \mathrm{E} \\
\end{array}$ & 659 & $\begin{array}{l}1 \mathrm{~m} \\
4.5 \mathrm{~m}^{2}\end{array}$ & 4.5 & 0.996 & 0.972 & 1.00 & 1.29 & 7.9 & 8.5 & 14,639 & $\begin{array}{l}15.6 \pm 1.8 \\
{[ \pm 1.1]}\end{array}$ \\
\hline \multicolumn{13}{|c|}{ Boulder inside the inner moraine arch } \\
\hline AVS-03-09 & $\begin{array}{l}48.00^{\circ} \mathrm{N} \\
11.38^{\circ} \mathrm{E} \\
\end{array}$ & 625 & $\begin{array}{l}2.7 \mathrm{~m} \\
8.4 \mathrm{~m}^{2}\end{array}$ & 5.5 & 1 & 0.969 & 1.00 & 1.1 & 4.6 & 8.4 & 12,638 & $\begin{array}{l}13.5 \pm 1.5 \\
{[ \pm 0.5]}\end{array}$ \\
\hline \multicolumn{13}{|c|}{ Inn glacier - deposits } \\
\hline AVC-04-01 & $\begin{array}{l}47.81^{\circ} \mathrm{N} \\
11.93^{\circ} \mathrm{E}\end{array}$ & 495 & $\begin{array}{l}2.5 \mathrm{~m} \\
80 \mathrm{~m}^{2}\end{array}$ & 4.5 & 1 & 0.972 & 1.00 & 1.2 & 6.1 & 7.5 & 15,372 & $\begin{array}{l}16.4 \pm 1.8 \\
{[ \pm 0.9]}\end{array}$ \\
\hline
\end{tabular}

Note: Samples were processed and measured at ETH Zurich tandem facility. The ${ }^{10} \mathrm{Be}$ concentrations and exposure ages are based on AMS standard S555 with a nominal value of $95.5 \mathrm{E}-12$ and an associated ${ }^{10} \mathrm{Be}$ half-life of $1.51 \mathrm{Ma}$.

* correction factor for the effect of topographic shielding and surface geometry [exponential depth profile, nucleonic attenuation length $155 \mathrm{~g}$ $\mathrm{cm}^{-2}$, muonic attenuation length $1510 \mathrm{~g} \mathrm{~cm}^{-2}$, coefficient $\mathrm{m}=2.3$ for the nucleonic and $\mathrm{m}=2.1 \mathrm{for}$ the muonic component].

+ blank-corrected.

$\S$ local production rate corrected for geometry, topography, sample thickness, erosion, snow cover, uplift and geomagnetic variations

\# corrected only for topographic shielding, geometry and sample thickness.

** exposure age corrected for all mentioned factors [section 3], error give the $1-\sigma$ uncertainty including analytical and systematic errors to be used when quoting absolute exposure age of boulder; errors in parenthesis give only the analytical uncertainty for comparison of different boulders in the same area.

(iii) The study area is presently covered by a closed forest. Corrections of the exposure ages for the effect of vegetation cover were calculated from biomass measurements from the Ebersberg forest, west of Munich (340 $\mathrm{t} \mathrm{ha}^{-1}$; data reported by CANNELL 1982). A closed vegetation cover was reconstructed for the late glacial Allerød period from drill cores proximal of the Inn glacier moraines (SCHMEIDL 1971; BEUg 1976). For the age calculations the duration of a vegetation cover is only assumed for the last $11 \mathrm{ka}$.

(iv) The Eastern Alpine foreland is subject to uplift movements; postglacial uplift rates for the Eastern Alps and the forelands are partly due to isostatic adjustment (Fiebig et al. 2004) and have been determined to be 1-2 mm $\mathrm{a}^{-1}$ (HöGGERL 1989). For the correction of production rate

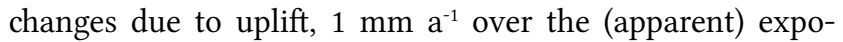
sure time is assumed in this study.

The exposure ages in the result chapters are given with the $1-\sigma$ uncertainty. For comparison and precision of the exposure ages among one another only the analytical un- certainties are given, whereas when the averaged exposure age of the moraines (landform age) are stated the total uncertainty including the analytical as well as the systematic uncertainties are given.

Radiocarbon ages were calibrated using the INTCAL09 curve (REIMER et al. 2009) and the online radiocarbon calibration program Oxcal 4.1 (https://c14.arch.ox.ac.uk/oxcal/ OxCal.html) (BRONK RAMSEY 2009).

\section{Study site - small mountain glaciation in the Bavarian Forest}

\subsection{Regional setting and glaciation in the study area}

The Bavarian Forest was repeatedly glaciated throughout the Pleistocene (Ergenzinger 1967; HAuner 1980, 1998; JerZ 1993; Pfaffl 1997) but is not glaciated at present. In the Bavarian Forest, glacial landforms have been recognized along the north to south-eastern slopes of the moun- 
tain ranges that rise above $1,300 \mathrm{~m}$ asl (RATHSBURG 1928; PriehäUSSER 1930; ErgenZINger 1967; Hauner 1980). The most recent glaciation in the Bavarian Forest was restricted to cirques and small valley glaciers (ERGENZINGER 1967; HAUNER 1980, 1998; JERZ 1993).

The study area is located in the small catchment $\left(2.8 \mathrm{~km}^{2}\right)$ of the Seebach River on the northern slopes of the Grosser Arber Mountain, the highest part of the Bavarian Forest (Fig. 3, 4). Three glaciers developed on the slopes of the Grosser Arber during glaciations; the largest of them was the Kleiner Arbersee glacier extending north into the Seebach catchment (PriehäUsser 1927; RAthsburg 1930; Pfaffl 1988, 1989). The wide saddle between Grosser and Kleiner Arber served as ice accumulation area (ERGENZINGER 1967; PfAffl 2001). During its last advance, the Kleiner Arbersee glacier extended about $2.5 \mathrm{~km}$ north from the saddle with a maximum lateral extent of $800 \mathrm{~m}$ (RAAB 1999). The glacier eroded a number of flat to slightly inclined cirques on the slopes of the valley head (ERGENZINGER 1967; MANSKE 1989). The shallow lake depression of the Kleiner Arbersee was excavated by a former glacier tongue (e.g. Bucher 1999). Moraines were deposited along the valley sides and to the north of the lake (Fig. 3, 4).

\subsection{Sampling sites}

A series of distinct lateral moraine ridges are preserved in the study area that flatten out into subdued, arcuate terminal moraines and are morphologically recognizable as ramping steps along the slope. The lateral moraine ridges are 5-10 m high and covered with many large moraine boulders (with a height above ground of up to $4 \mathrm{~m}$; Fig. 2, Tab. 1). Moraine ridges are distinct on the eastern side of the catchment. On the western side they fade out on top of bedrock on the steep slopes south of the lake (Fig. 3, 4). The terminal and lateral moraines deposited by the Kleiner Arbersee glacier consist of clast-rich sandy to silty, bouldery, massive diamictons (RAAB \& VÖLKEL 2003).

The outermost lateral moraine WI (terminology after RAAB 1999; Fig. 3, 4) splits into two moraine ridges at around $900 \mathrm{~m}$ asl. This double-crested lateral moraine turns west about $50 \mathrm{~m}$ further down the slope and forms a set of terminal moraines. The outer ridge WIa passes into a shallow terminal moraine approximately $600 \mathrm{~m}$ north of the lake shore; the inner ridge of the terminal moraine WIb forms the southern part of the set of terminal moraines about $500 \mathrm{~m}$ north of the lake.

A morphologically distinct $(\sim 5-10 \mathrm{~m}$ high) terminal moraine WII was deposited by the downwasting glacier proximal to the WI moraines, about $400 \mathrm{~m}$ north of the lake. The terminal moraine WII passes into a distinct lateral ridge on the eastern side of the catchment. Inside the moraine WII and north of the lake a hummocky relief with numerous kettle holes and a few shallow ridges persists.

Along the eastern slopes of the catchment and ice-proximal of the WI and WII lateral moraines, two lateral moraine ridges are morphologically distinguishable (WIII and WIV; RAAB 1999). Both moraine ridges flatten out at the northern lake shore. A subdued ridge of glaciolacustrine sediments (MAHR 1998; RAAB 1999) dams the lake to the north and is covered with large moraine boulders.
On the southern side of the lake, the valley of the Seebach is narrow and vertical bedrock cliffs are exposed on the western catchment side. The bedrock consists of jointed sillimanite-cordierite gneiss (Troll 1967a, b; ОTт \& ROHRMÜLLER 1998). Glacial erosion occurred mainly along these joint planes (RATHSBURG, 1928; RAAB 1999). The bedrock outcrops show glacial striations on protruding quartz veins indicating glacial abrasion.

\subsection{Sample description and results of surface exposure dating}

In the study area a total of 16 samples were taken from moraine boulders and bedrock surfaces (Fig. 3, 4, Tab. 1). Furthermore, we took samples from three glacially polished quartz veins south of the lake (KUBIK \& Reuther 2007; REUTHER 2007), however, only the ${ }^{10} \mathrm{Be}$ nuclide concentration of the three surface samples will be included in the following discussion.

\section{Terminal and lateral moraines (WI)}

Four samples were taken from moraine boulders on the crest of the outer lateral ridge WIa, two come from boulders on the inner ridge crest of the lateral-terminal moraine set WIb. Four samples were taken on the lateral moraine ridge WI just before it splits into the two ridges WIa and WIb.

The oldest exposure ages were measured in boulders located on the outer ridge WIa $(20.7 \pm 0.6 \mathrm{ka} ; 19.2 \pm 0.5 \mathrm{ka}$; $18.4 \pm 1.1 \mathrm{ka})$. The boulders located on the inner ridge WIb yield exposure ages, which are identical and younger than those on the outer ridge $(18.7 \pm 0.7 \mathrm{ka} ; 18.7 \pm 0.7 \mathrm{ka})$. Boulder BW-03-19 $(17.4 \pm 0.5 \mathrm{ka})$ on the inner side of the moraine is located ice-proximal to the ridge and its exposure age gives the age of the downwasting of the glacier from the WI moraine.

The exposure ages measured from the boulders on the lateral moraine WI before it splits into WIa and WIb are more scattered. Boulder BW-03-18 $(15.0 \pm 0.8 \mathrm{ka})$ on the lateral moraine WI is partially embedded in the proximal side of the moraine. It stands $0.9 \mathrm{~m}$ above the ground on its ice-proximal side and only $10 \mathrm{~cm}$ on its ice-distal side. The young age might indicate a persistent thin sediment cover and exhumation of the surface well after deposition of the boulder. Boulder BW-03-07 $(16.9 \pm 0.7 \mathrm{ka})$ on the outer moraine WIa is a tall $(2 \mathrm{~m})$ boulder with a small basal plane area $\left(4.5 \mathrm{~m}^{2}\right)$ that is slightly tilted down slope. The boulder might have slightly rotated, explaining the 'too young' exposure age in comparison to the adjacent boulders. No explanation for the comparatively young exposure age of the massive boulder BW-03-17 $(15.9 \pm 1.0 \mathrm{ka})$ on the lateral moraine WI is obvious. The boulder might have been toppled or tilted when nearby trees or trees growing on top of the boulder tipped over (e.g. CERLING \& CRAIG 1994).

In summary, the double crest indicates that the set of outermost terminal and lateral WI moraines has been deposited by two different glacial oscillations. The initial glacial advance occurred before $20.7 \pm 2.0 \mathrm{ka}$. The exposure ages show a stratigraphical order from the oldest boulder located on the outer crest (landform age $19.1 \pm 2.0 \mathrm{ka}$ ) to the possibly slightly younger boulders on the inner crest (landform age $18.7 \pm 1.8 \mathrm{ka}$ ). 


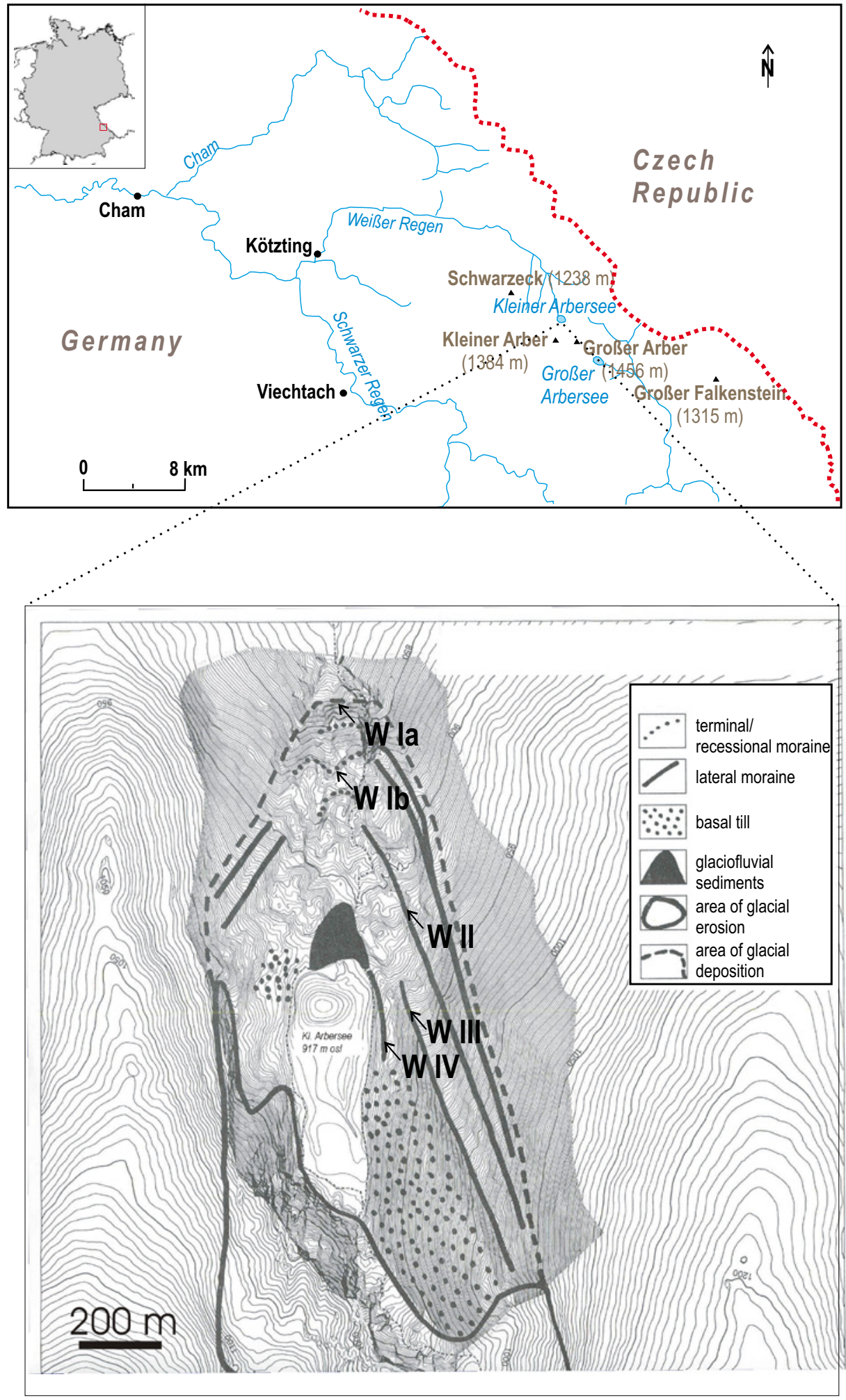

Fig. 3: Sketch map of Bavarian Forest and the location of the study area. Map of the glacial deposits around the Kleiner Arbersee from RAAB (1999).

Abb. 3: Schematische Skizze des Bayerischen Waldes und Lage des Untersuchungsgebietes. Karte der glazialen Ablagerungen um den Kleinen Arbersee von RAAB (1999)

\section{Recessional/readvance moraine (WII)}

Moraine WII is located only $100 \mathrm{~m}$ to the south of the terminal moraines. Two boulders right on top of the moraine crest (Fig. 3, 4) yield exposure ages of $17.4 \pm 0.6 \mathrm{ka}$ and $17.2 \pm 0.5 \mathrm{ka}$. A third boulder (BW-03-04) on the same crest located between the two other boulders yields a much younger exposure age $(15.4 \pm 0.6 \mathrm{ka})$. The boulder is massive and stands high above the surface. The young exposure age must be a result of either toppling of the boulder by a falling tree or spalling of the surface. The two well measured, identical exposure ages yield a landform age of 17.3 $\pm 1.6 \mathrm{ka}$.

\section{Lake moraine}

Two samples were taken at the north-western end of the lake, where the lateral moraine ridges WIII and WIV fade out (Fig. 3, 4). The boulders are located on the end of the lateral moraines. One sample was taken from the ridge that dams the lake to the north (BW-04-03).

These three boulder surfaces yield exposure ages of $15.8 \pm 0.6 \mathrm{ka}, 15.9 \pm 1.4 \mathrm{ka}$ and $15.0 \pm 0.5 \mathrm{ka}$. The landform age of this moraine can be calculated to $15.7 \pm 1.7 \mathrm{ka}$ with an arithmetic mean of the ages of $15.5 \mathrm{ka}$ and a median of $15.7 \mathrm{ka}$. 


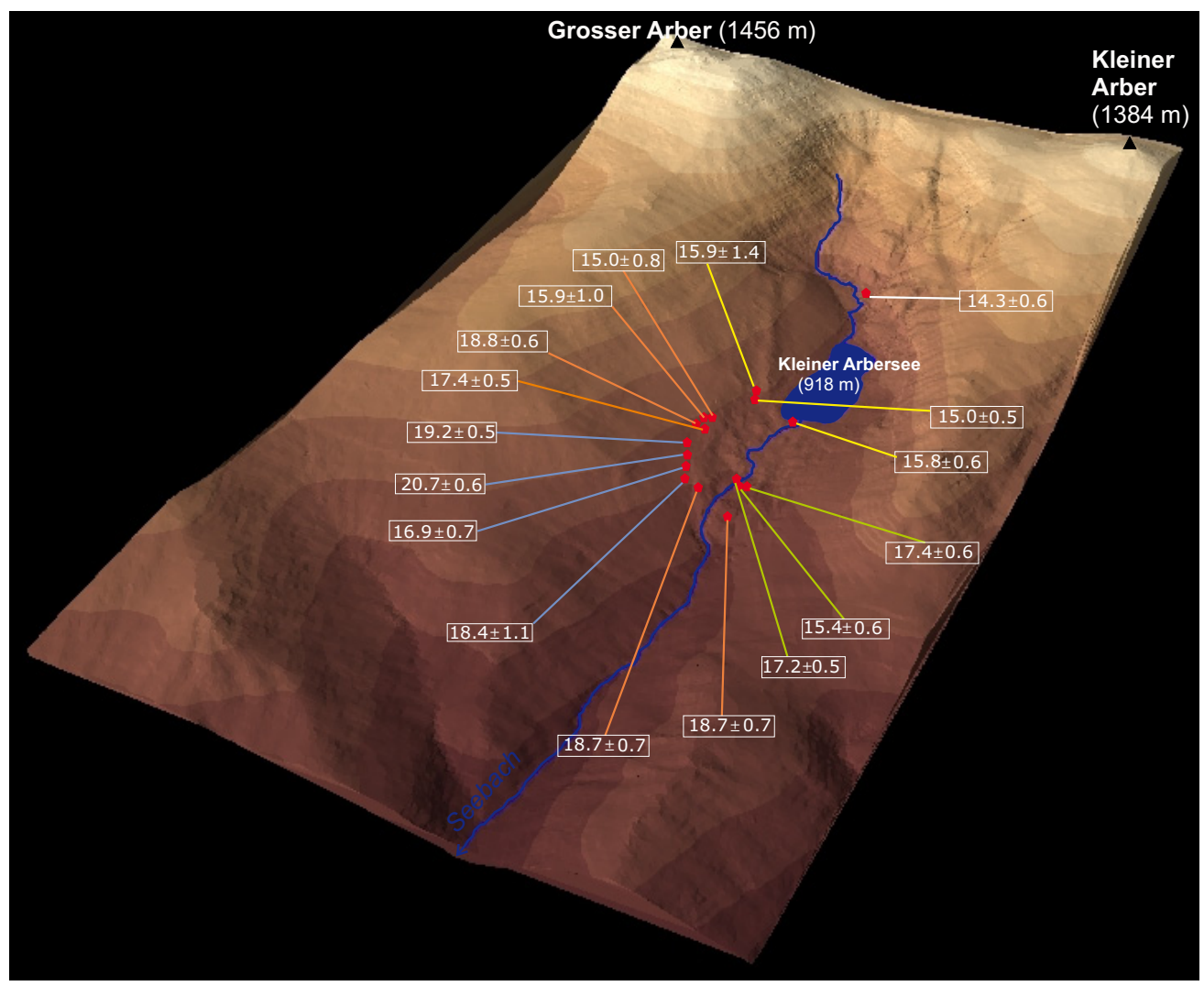

Fig. 4: Digital elevation model (DEM) of the study area in the Bavarian Forest, the location of the boulders and the respective exposure ages with the 1- $\sigma$ analytical uncertainty. The moraines as well as the steep bedrock cliffs are well recognizable on the DEM.

Abb. 4: Digitales Geländemodell des Untersuchgebietes im Bayerischen Wald, Position der Moränenblöcke und den entsprechenden Expositionsaltern und Angabe der 1- $\sigma$ Abweichung. Die Moränenzüge sowie die steilen Felsabbrüche sind im Geländemodell gut erkennbar.

\section{Glacially polished quartz vein south of the Kleiner Arbersee}

Samples were taken from a glacially polished quartz vein in a steep $\left(70-80^{\circ}\right)$ bedrock cliff south of the lake (KAS) $1.5 \mathrm{~m}$ above the ground surface. The outermost slices of the three bedrock cores (KAS-1-01, KAS-2-01, KAS-3-01) were dated to $14.3 \pm 1.8 \mathrm{ka}(14.0 \pm 0.5 \mathrm{ka}, 14.6 \pm 0.6 \mathrm{ka}, 14.2 \pm 0.7 \mathrm{ka})$.

\subsection{Discussion of results - Bavarian Forest}

Moraine boulders on the late Würmian Kleiner Arbersee glacier yield stratigraphically consistent exposure ages. Boulders on the outermost moraine WIa give the oldest surface exposure ages, whereas moraine boulders on the proximal ridges become progressively younger. The consistency of the exposure ages documents the reliability of surface exposure dating in the study area and indicates that the exposure ages reflect the time of initial moraine stabilization after the glacier stopped delivering material onto the ridges. The well-preserved and distinct ridge morphology of the moraines indicates that thawing of dead ice bodies did not largely modify the moraines after deposition. In the study area a hummocky relief that might indicate the presence of dead ice after deglaciation is only present between the readvance moraine WII and the lake moraine, not on the moraines.

Deposition of the moraine boulders on the terminal moraines WI occurred no later than $20.7 \pm 2.0 \mathrm{ka}$. Moraine boulders on the outer ridge WIa were stabilized around $19.1 \pm 2.0 \mathrm{ka}$. Before $18.7 \pm 1.8 \mathrm{ka}$, the glacier melted back $50-100 \mathrm{~m}$ from its terminal position WIa and accumulated the inner ridge WIb, resulting in the double-ridge morphology of the terminal moraines. One could argue that the moraine boulder of $20.7 \pm 2.0$ ka shows inherited nuclide abundance as the other boulders of the same moraine ridge cluster around 19.1 $\pm 2.0 \mathrm{ka}$. However, the 20.7-ka boulder has a smooth and rounded surface indicating a rounding of the boulder and thus erosion prior to its deposition. Consequently, inheritance seems unlikely. Furthermore, the boulder is located on the outer shoulder of the terminal moraine ridge WIa, where stratigraphically the oldest boulders is to be expected.

The exposure age of boulder BW-03-19 suggests that the glacier melted back from the inner ridge of the moraine set WI at approximately $17.4 \pm 1.8 \mathrm{ka}$. The recessional moraine WII was deposited during an oscillation of the backwasting glacier at $17.3 \pm 1.6 \mathrm{ka}$.

The exposure ages from the two boulders on the lateral moraines at the northern lake shore and the boulder deposited on the arcuate ridge which dams the lake were deposited during a glacial readvance, around $15.7 \pm 1.7 \mathrm{ka}$. Deformed laminated glaciolacustrine sediments at the northern lake shore (RAAB \& VÖLKEL 2003) are indicative of such a postdepositional readvance of the glacier.

As indicated by the exposure ages on the southern side of the lake, the glacier wasted back from the lake basin around $14.5 \pm 1.8 \mathrm{ka}$. These ages are in good accord with the radiocarbon ages that imply an ice-free lake basin no later than 13.9-15.0 cal ka BP $\left(12,311 \pm 372{ }^{14} \mathrm{C}\right.$ yr; RAAB 1999) and with radiocarbon ages that indicate a backwasting of the Kleiner Arbersee glacier into the cirque locations by 12.5-12.9 cal ka BP $\left(10,746 \pm 152{ }^{14} \mathrm{C}\right.$ yr; RAAB 1999).

The late Würmian chronology of the Kleiner Arbersee glacier indicates a deposition of the terminal moraines WI during a period of approximately 3,000 years and backwasting from its terminal moraines not before $17.4 \pm 1.8 \mathrm{ka}$. The melting of the glacier was therefore slow as compared to 


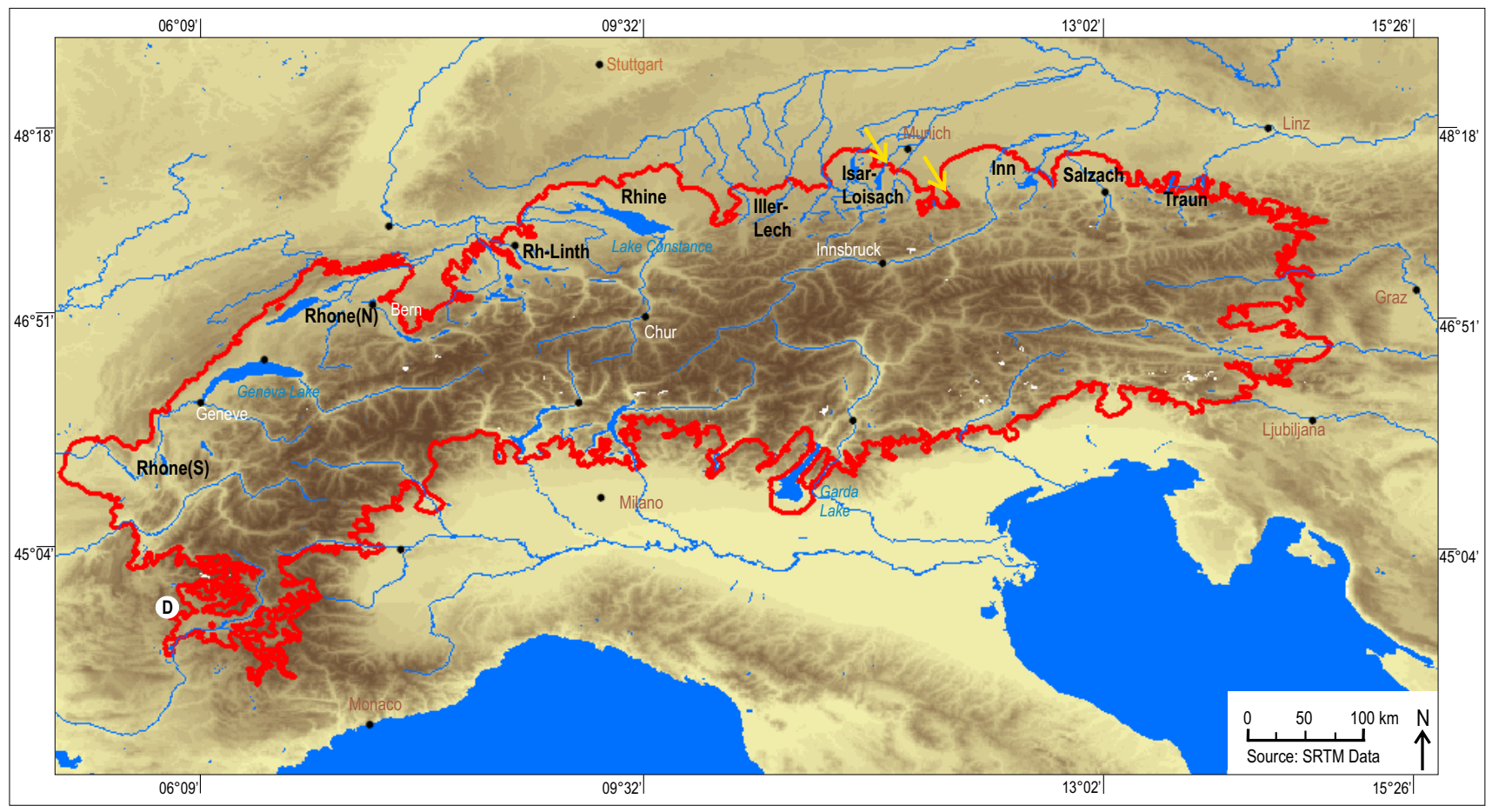

Fig. 5: Shaded relief of the Alps based on elevation data from the Shuttle Radar Topography Mission (SRTM). The red line marks the extent of the late Würmian Alpine ice cover (EHLERS \& GIBBARD 2004b), the yellow arrows mark the two sampling sites on the northern Alpine Foreland.

Abb. 5: Digitales Geländemodell der Alpen erstellt aus Daten der Shuttle Radar Topography Mission (SRTM). Die rote Linie beschreibt die spätwürmzeitliche alpinen Eisausdehnung (EHLERS \& GIBBARD 2004b), die gelben Pfeile markieren die Untersuchungsgebiete im nördlichen Alpenvorland.

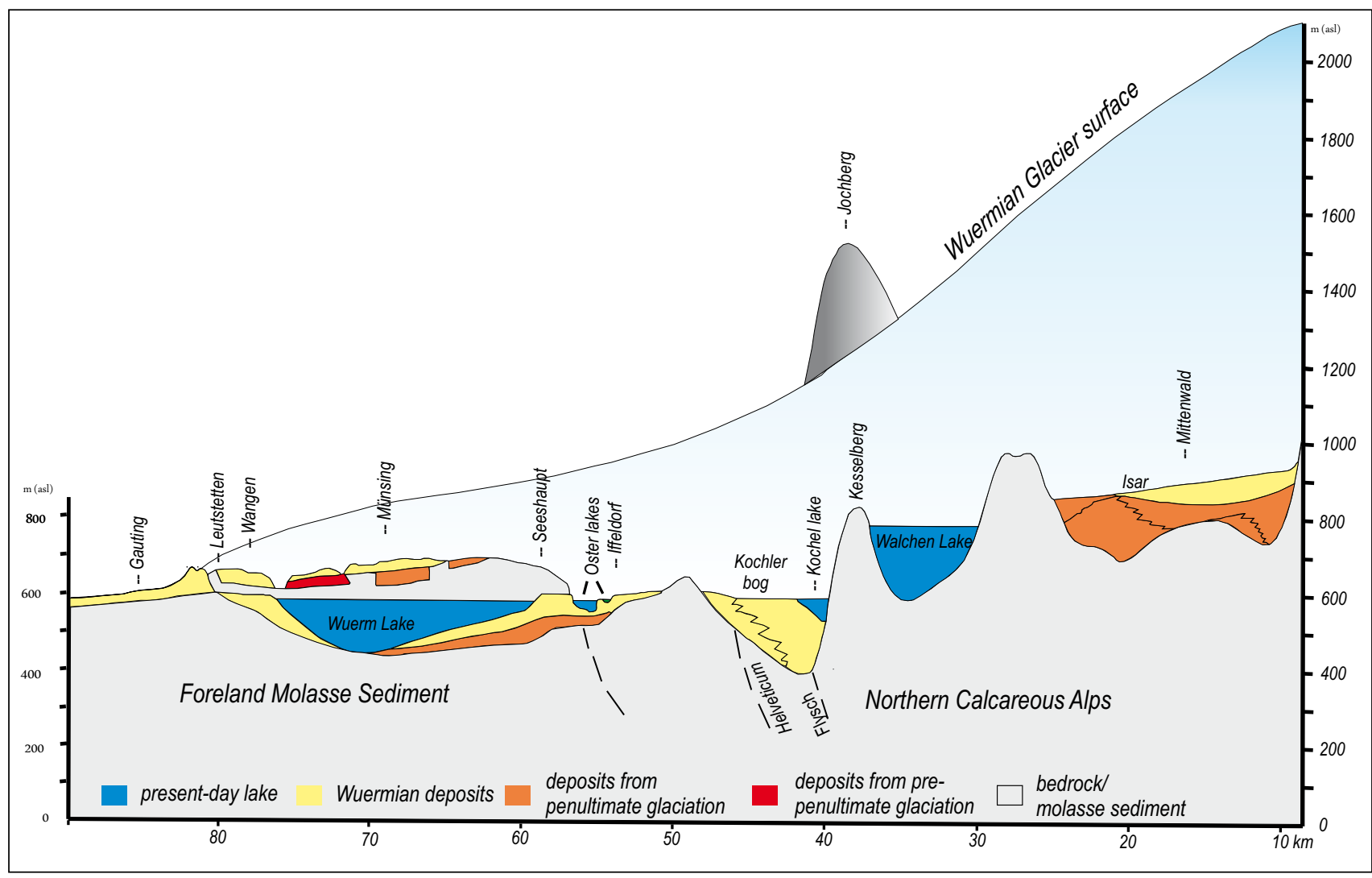

Fig. 6: Reconstructed ice surface of the Würmian piedmond lobe of the Isar-Loisach glacier with sketch of the the local geology (modified from MEYER \& SCHMIDT-KALER 1997, after map by VAN HUSEN 1987). A cross section through the Würmsee and the terminal moraines of the study area.

Abb. 6: Rekonstruierte Eisoberfläche des würmzeitlichen Piedmontlobus des Isar-Loisach Gletschers mit einer schematischen Darstellung der lokalen Geologie (abgewandelt von MEYER \& SCHMIDT-KALER 1997, nach einer Karte von VAN HUSEN 1987). Ein Querschnitt des Würmsees und den Endmoränen im Untersuchungsgebiet. 


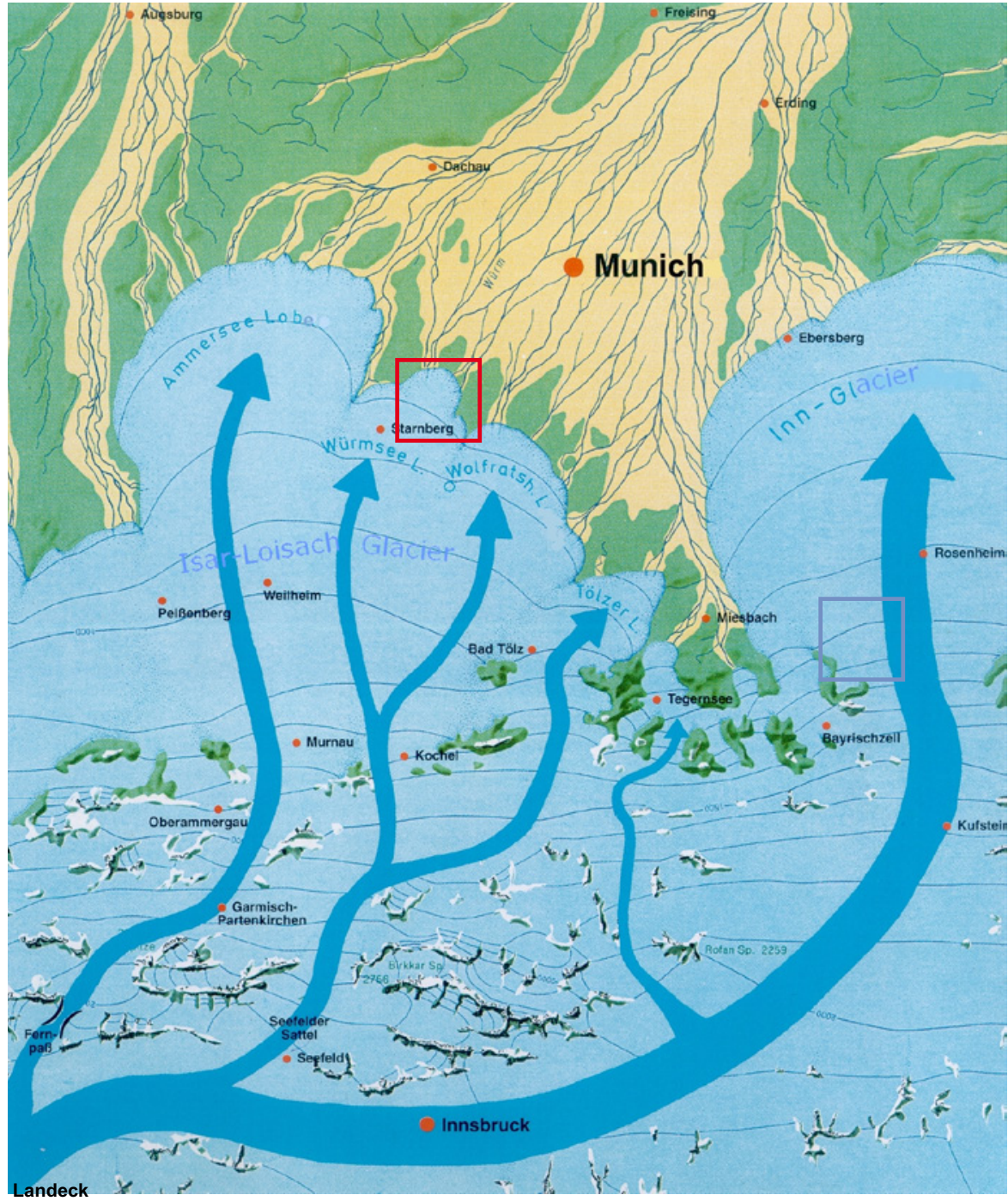

Fig. 7: Reconstructed late Würmian ice cover and the flow direction of ice streams that fed the Isar-Loisach and the Inn-glacier (modified from MEYER \& SCHMIDT-KALER 1997, after map by VAN HUSEN 1987). The squares mark the two sampling locations.

Abb. 7: Rekonstruierte Eisoberfläche des würmzeitlichen Eisbedeckung und Eisflußrichtung der Eisströme, die den Isar-Loisach und den Inngletscher gespeist haben (abgewandelt von MEYER \& SCHMIDT-KALER 1997, nach einer Karte von VAN HUSEN 1987). Die Vierecke markieren die Probennahmestellen. the deglaciation in the Alps (see below). Melting back from the inner moraine ridge of the terminal moraine WIb, which stabilized around $18.7 \pm 1.8 \mathrm{ka}$, to the recessional moraine WII (horizontal distance about $120 \mathrm{~m}$ ) took place over a period of about 1,400 years. Downwasting of the glacier from the recessional moraine WII into the lake basin (horizontal distance about $400 \mathrm{~m}$ ) and the readvance to the lake moraine happened over about 2000 years.

\section{Study site - large piedmont glaciers on Eastern Alpine Foreland}

\subsection{Regional setting and ice surface geometry}

During Pleistocene glaciations, the high elevated central chain of the Eastern Alps was the main ice accumulation area for the Eastern Alpine glaciation (VAN HUSEN 1997). In different locations, such as the upper Inn valley, ice domes formed (FLORINETH \& SCHLÜCHTER 1998; FLORINETH 1998). Furthermore, extensive glaciers accumulated on the high elevated plateaus of the Northern Calcareous Alps (vAN HusEn 1997). During glaciations, the valleys were entirely filled with ice, and glaciers frequently overflowed passes (BECK 1932; HANDTKE 1980; JäCKLI 1970; vAN HuSEN 1987). By reaching the limit of the Alps, the glaciers spread out as large piedmont lobes (Fig. 5). The glaciers excavated basins at the foothills of the Alps and large overdeepened basins on the forelands which were occupied by lakes following deglaciation (Fig. 6; Troll 1924; FrANK 1979; Jerz 1987a, b; KLEINMANn 1995; van Husen 2000). At present, the Eastern Alps are only glaciated at higher elevations, with an ELA around 2800-2900 m asl (KERSCHNER 1996).

The study area is the region of abandoned terminal moraines from the late Würmian Isar-Loisach glacier located south-west of Munich. A single exposure age was determined from deposits of the late Würmian piedmont lobe of the Inn glacier, south-east of Munich (Fig. 7).

The glacier complexes of the Inn and the Isar-Loisach glacier were tightly connected by ice transfluence (Fig. 7). During the late Würmian glaciation glaciers extending from the central Alpine ice accumulation areas merged around Landeck and build-up a thick ice mass in the Inn valley (vAN Husen 2000, 2004). The drainage through the Inn valley was already blocked by advancing tributary glaciers further down-valley. The ice congestion and increase in ice thickness resulted in an ice transfluence of the Inn valley ice to the north into the headwaters of the Isar and the Loisach (Fig. 7). The ice overflowed the divide in the Northern Calcareous Alps about 400-600 m above the bottom of the Inn valley (PENCK 1882; DreEsBACH 1985; JERZ 


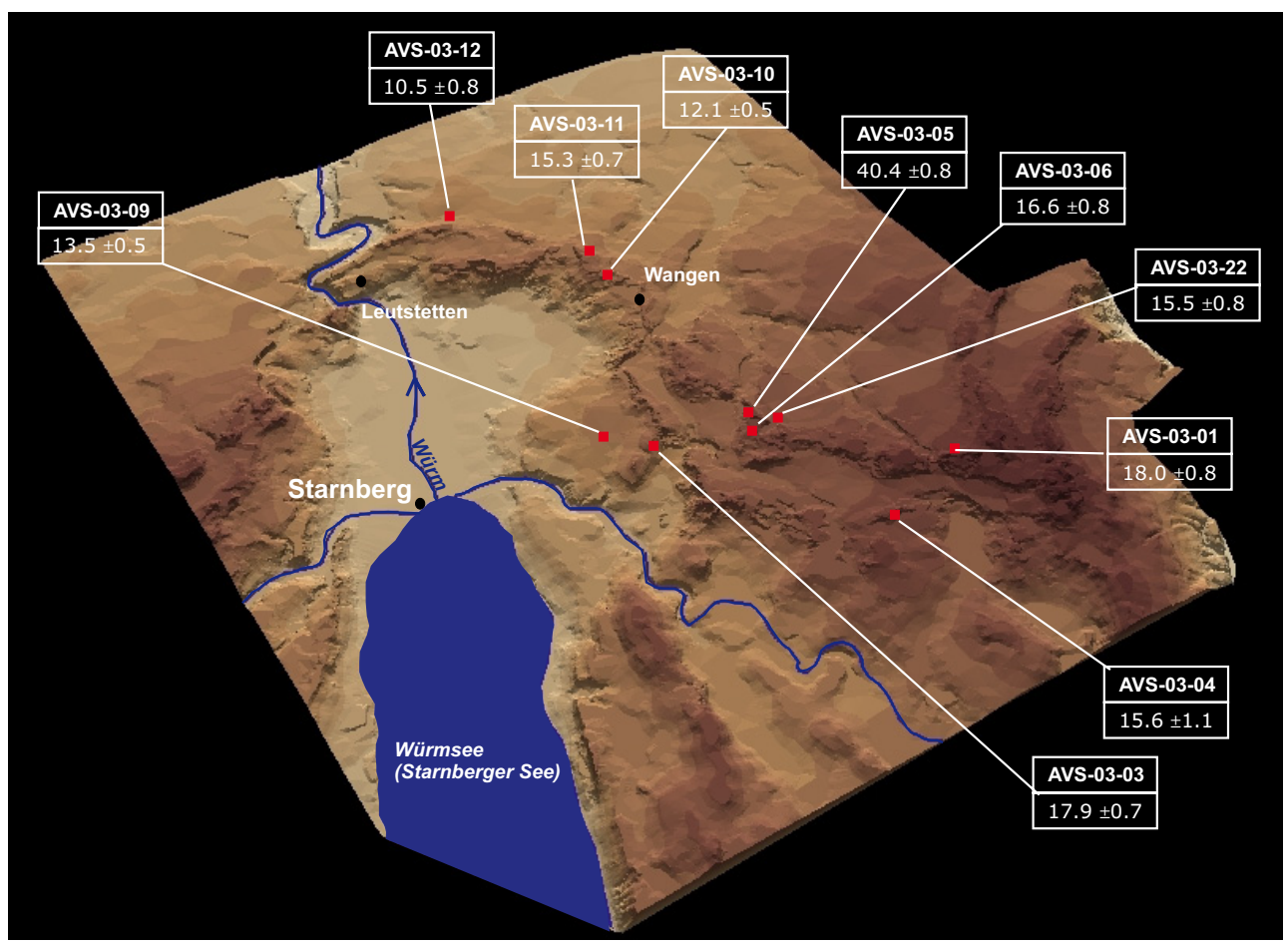

Fig. 8: DEM of the study area around the Würm Lake, the location of the sampled boulders and the respective exposure ages with the 1- $\sigma$ analytical uncertainty. The DEM is based on contour lines from a 1:5,000 map and is 5-times vertically exaggerated. The arcuate moraines and the different

ridges (see text) are well recognizable in the DEM.

Abb. 8: Digitales Geländemodell des Untersuchunggebietes um den Würm See, die Lage der beprobten Moränenblöcke und die entsprechenden Expositionsalter und Angabe der 1- $\sigma A b$ weichung. Das Geländemodell basiert auf einer 1:5.000 Karte und 5-facher Überhöhung. Die gebogenen Moränenwälle und verschiedenen Moränenzüge (siehe Text) sind im Geländemodell auszumachen.

1993; VAN HUSEN 2000). The Isar-Loisach glacier itself had only a small local accumulation area in the Northern Alps. The large Isar-Loisach piedmont lobe extended about $60 \mathrm{~km}$ onto the forelands.

\subsection{Glacial setting and sampling sites}

The Würmian Isar-Loisach glacier deposited sets of arcuate terminal moraine ridges around the overdeepened lake basin of the Würmsee and the Ammersee (Fig. 8; Jerz 1979, 1993; Frank 1979; Feldmann 1992). During its initial late Würmian advance the Isar-Loisach glacier as well as the Inn glacier (Troll 1924; GrIPP \& EBERS 1957) deposited small moraines, only preserved in a few locations or diamictic layers without morphologically visible ridges (JERZ 1987a, b; FIEBIG et al. 2004). These deposits are called the outer maximum or 'supermaximum' advance. High-prominent moraines a few tens to hundred meters south of the outer maximum moraines were referred to as the Würmian maximum moraines before the outer maximum extent was recognized. Based on field evidence, it is assumed that the glaciers melted back shortly after they reached their outer maximum position and subsequently deposited the high prominent 'maximum' moraine (JERZ 1993; FIEBIG et al. 2004). Just proximal of the maximum late Würmian moraines, recessional and/or readvance moraines during deglaciation were deposited. In a few locations around the Würmsee, these ridges were pushed into one wide ridge (Fig. 8).

The ridges are in parts well-preserved but disrupted by numerous kettle holes, which today are filled with fens or seasonal kettle ponds (ENGELSCHALK 1971; GRUBE 1983; JERZ 1987a, b). The steep-crested ridges are up to $40 \mathrm{~m}$ high and a couple hundred meters wide with locally flat tops (GRUBE 1983). The moraine ridges are broken up in multiple smaller ridges and small knolls. Meltwater channels fre- quently intersect the moraine ridges (Fig. 8; JERZ 1987a, b).

The Inn glacier spread out onto the foreland as a large piedmont lobe east of the Isar-Loisach glacier and excavated a large basin near the foothills of the Alps (Rosenheimer Becken). From this basin glacier lobes spread out radially (Fig. 7; PENCK \& BRÜCKNER 1901/09; TROLL 1924; Hormann 1974; RATHJEns 1985). The sequence of moraines and glacial deposits around the Inn glacier is very similar to that described for the former Isar-Loisach glacier (Troll 1924, 1925, 1957). The Isar-Loisach glacier advanced to its maximum extent later than the Inn glacier (Graul 1957).

Sample description and results of surface exposure dating Nine erratic boulders were sampled from the terminal moraine complex of the Isar-Loisach glacier surrounding the Würmsee (Fig. 8, Tab. 2). No erratic boulders were found on the supermaximum position. One massive boulder was sampled on deposits from a late glacial glacier halt position of the Inn glacier.

Erratic boulders are rarely found on the moraine ridges on the Alpine foreland at present. The boulders are usually fairly small (1-1.5 m high; Fig. 9). All sampled boulders are of crystalline lithologies with a provenance in the Central Alps.

Six boulders were sampled on the maximum moraine ridge, whereas only two suitable boulders could be sampled on the first readvance and/or recessional moraine ridge. One sample was taken from a boulder just proximal of the inner moraine ridge (Fig. 8).

The measured exposure ages of the moraine boulders scatter from $40 \mathrm{ka}$ to $14 \mathrm{ka}$. Three of the boulders are excluded from further interpretation as they are considered outliers. The six remaining boulders form a central age cluster with two older boulders and a tailing out of the age distribution towards the young. The ages range from $18.0 \pm 1.9 \mathrm{ka}$ to $15.3 \pm 1.7 \mathrm{ka}$. 
Out of the three outliers, two boulders (AVS-03-09, AVS-0310) showed chipmarks at the sides of the boulder, whereas the sampled surfaces seemed untouched. They yield anomalous young ages (around 12-13 ka) that do not overlap within the $1-\sigma$ uncertainty with the age distribution of the other boulders. The boulder surfaces might have either been chipped without obvious evidence or the boulder might have toppled during the impacts. The third outlier (AVS-03-05) is a boulder with an anomalously old exposure age (around $40 \mathrm{ka}$ ) which we attribute to preexposure of the boulder and insufficient glacial erosion during the transport (inherited nuclide abundance), not an unusual phenomenon among moraine dating studies (PUTKONEN $\mho$ SWANSON, 2003).

The other moraine boulders show an overlapping age distribution. The oldest ages were obtained by boulder AVS03-01 $(18.0 \pm 1.9 \mathrm{ka})$ on the crest of the outer moraine ridge of the former Isar-Loisach glacier and by boulder AVS-03-03 $(17.9 \pm 1.9 \mathrm{ka})$ on the crest of the inner moraine ridge (Fig. 8).

Boulder AVC-04-01 (16.4 $\pm 1.8 \mathrm{ka})$ was sampled from glacial deposits of the late Würmian Inn glacier because it is the largest boulder found in the study area (Fig. 7, 9, Tab. 2). The boulder shows chipmarks on its west side, however, not on the surface. It is located on glacial deposits of the downwasting Inn glacier at the edge of the central Rosenheimer Becken, on a wide, not morphologically obvious rampart above the basin. This wide rampart might either represent a moraine ridge of the late glacial Olkofener Stadium (Troll 1924; Jerz 1970a) or represent a till-covered, molasses-cored bedrock ridge (Troll 1924) in which case the boulder dates the downwasting of the Inn glacier.

\subsection{Discussion of results - Eastern Alps}

The moraine boulders on the terminal moraines of the Würmian Isar-Loisach glacier yield exposure ages that scatter from $18.0 \mathrm{ka} \pm 1.9$ to $15.3 \pm 1.7 \mathrm{ka}$ with an age cluster around $18 \mathrm{ka}$ and a tailing out towards younger ages, falling well into the late Würmian. However, the distribution of boulder ages does not show a chronological order with respect to their location in the sense that ages are younger on the inner moraines (Fig. 8). The boulder situated on sediments of the downwasting Inn glacier yield an exposure age that is indistinguishable from ages determined on the terminal moraines of the Isar-Loisach glacier.

The timing of the maximum Würmian glacial extent in the Eastern Alps is bracketed by a few numerical ages from different locations throughout the Eastern Alpine that suggest a similar timing of the ice advance and deglaciation in the area (e.g. Furrer 1991; Schoeneich 1998; Preusser 2004; Ivy-Ochs et al. 2008; Kerschner et al. 2008). No numerical age has yet been derived from glacial deposits of the Isar-Loisach glacier. However, the ice-transfluence situation implies an ice-dynamic connection between the IsarLoisach and the Inn glacier (Fig. 7). During deglaciation the Isar-Loisach glacier was cut off from its central alpine accumulation area by the time when the ice table in the Inn valley sank below the elevation of the ice transfluence. Therefore constraints on the timing of deglaciation of the Inn glacier yields broad information on the deglaciation of the Isar-Loisach glacier.
Published numerical chronologies suggest that the initial glacial advance of the Inn glacier in the late Würmian occurred around 25-33 cal ka BP as numerical ages from lacustrine sediments overlain by lodgement till in the Inn valley $\left(30.3-33.0 \mathrm{cal}\right.$ ka BP $\left[26,800 \pm 1300{ }^{14} \mathrm{C}\right.$ yr BP]; FLIRI et al. 1970) and dated organic material in fluvioglacial deposits underlying Würmian till of the Inn glacier on the Alpine foreland (24.9-28.0 cal ka BP $\left[21,900+1230 /-1070^{14} \mathrm{C}\right.$ yr BP]; HABBE et al. 1996) suggest (Fig. 10). Following the peak of the maximum Würmian glaciation, the Inn glacier piedmont lobe disintegrated rapidly (REITNER 2005, 2007). A few radiocarbon ages on pollen bracket the late glacial vegetation history and thus put restraints on the climatic boundary conditions during deglaciation. An ice-free lower Inn valley around $17.4-16.8 \mathrm{cal} \mathrm{ka} \mathrm{BP}\left(13,980 \pm 240{ }^{14} \mathrm{C}\right.$ yr $\mathrm{BP}$ ) is suggested by the basal age of a peat bog that developed about $300 \mathrm{~m}$ above the Inn valley near Innsbruck (Bortenschlager 1984a, b; Oeggl 1992). In tributaries of the Inn River, the late glacial Gschnitz advance was exposure dated to $15.5 \pm 1.8 \mathrm{ka}$ (Ivy-Ochs et al. 2006a) and the Egesen (Younger Dryas) advance to $12.2 \pm 1.1 \mathrm{ka}$ (Ivy-Ochs et al. 2006b). Similar ages were derived from the neighboring Rhein and Traun glaciers (e.g. VAN Husen 1977; GeyH o SCHreiner 1984; Preusser 2004).

In summary, numerical ages determined for the deglaciation of the Inn glacier show that the entire ice body had disintegrated and melted back into the Inn tributaries well before 16-15 cal ka BP by the time when a late glacial readvance of glaciers (= Gschnitz advance) in the tributaries occurred (Fig. 10).

The here presented exposure ages measured on the terminal moraines of the Isar-Loisach glacier, about $60 \mathrm{~km}$ north of the fringes of the Alps do not corroborate this independently derived chronology. However, as the exposure ages do not cluster tightly and are not internally coherent (Fig. 8), we suggest that the age distribution does not reflect the time of moraine deposition or abandoning of the moraine but rather the final moraine stabilization. Reasoning that the surface exposure ages measured here yield the true age of the moraine deposition would be in contradiction to all published numerical chronologies (see above) and field evidence for rapid deglaciation of Eastern Alpine glaciers (REITNer 2005, 2007; Ivy-Ochs et al. 2008).

The scatter in the measured exposure ages can be explained by periglacial surface processes or thawing of dead ice that exposed the boulder surface considerably after the boulder was deposited by the glacier (Fitzsimons 1996; DyKe \& SAVElle 2000; Everest \& BRADWELl 2003). Boulders embedded in the moraine matrix which are exhumed during moraine degradation processes document the time of landform stabilization rather than the moraine deposition time.

Thawing of dead ice and periglacial slope processes have affected the moraine morphology in the study area (GRUBE 1983) and the scatter in the age distribution presumably reflects the stabilization of the moraines. The described hummocky relief and the multiple kettle hollows in the moraines (Fig. 8, 11) suggest that following the deposition of the terminal moraines around the Würmsee the glacier melted down, separating dead ice bodies and leaving behind ice-cored moraines. Ice-contact sediments like kame terraces show that the downwasting Isar-Loisach glacier 

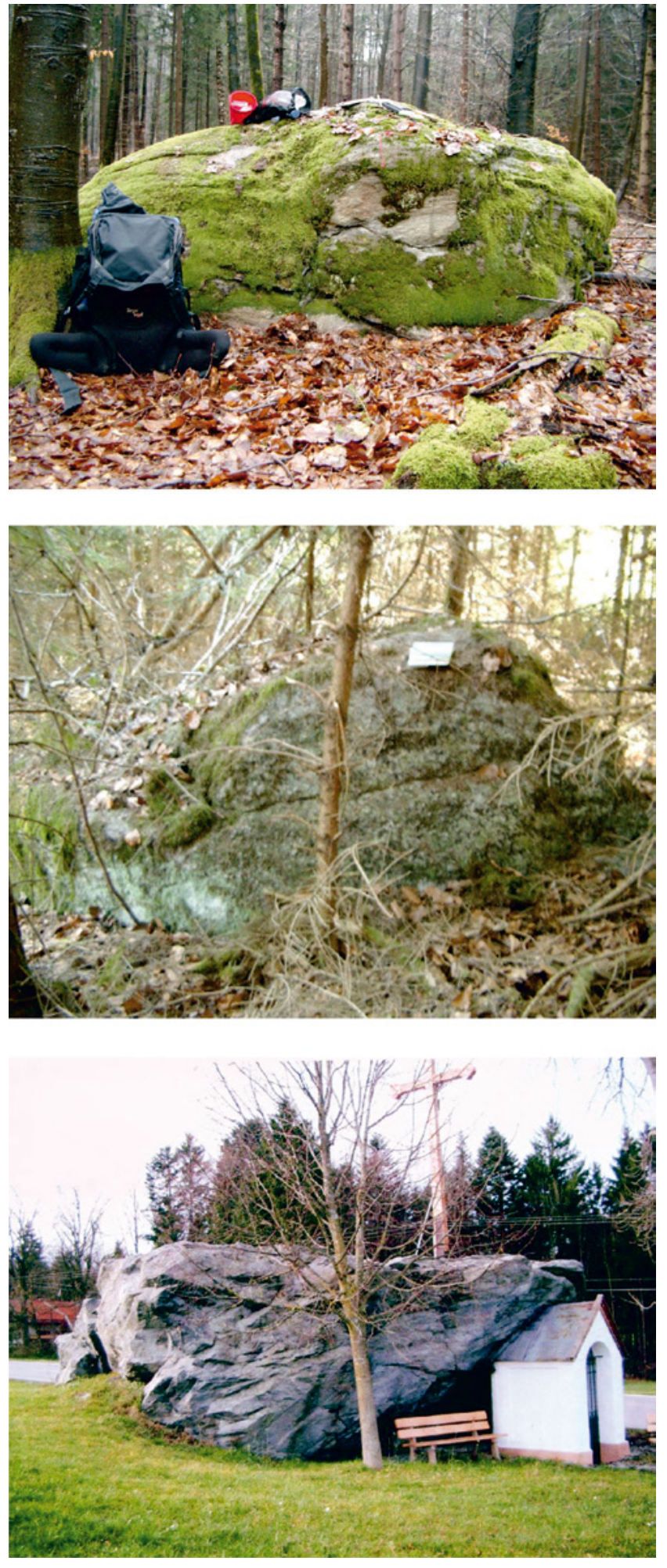

Fig. 9: Field photographs from the Alpine Foreland. First picture depicts boulder AVS-03-01, second picture shows boulder AVS-03-22 and third picture shows the large erratic boulder from the Inn glacier deposits AVC-04-01.

Abb. 9: Geländeaufnahmen aus dem Alpenvorland. Das erste Photo zeigt den Moränenblock AVS-03-01, das zweite Bild den Block AVS-03-22 und das dritte Bild den großen erratischen Block von den Ablagerungen des Inngletschers AVC-04-01.

disconnected a large dead ice body that filled the lake basin of the Würmsee during deglaciation (FrANK 1979; BLUdAU \& Feldmann 1994; KleinMann 1995; Feldmann 1998). The hummocky relief with many dead ice hollows and drumlin fields south of the Würmsee basin give further evidence for thawing of debris-covered dead ice complexes well after the initial deglaciation (e.g. Rothrletz 1917; Troll 1937; BLUdAu \& FELDMANN 1994).

Thawing of dead ice and periglacial slope processes on the moraines in the study area can explain, firstly, the large spread in exposure ages that tail out towards the young, secondly, the fact that the boulder ages do not reflect their geographic position with respect to the former ice margin (especially true for the age of the boulder from the Inn glacier deposits), and, thirdly, the fact that the two oldest boulders (AVS-03-01, AVS-03-03) are located right on top of well preserved ridges which were likely the first to stabilize. The younger boulders are located on moraine crests but are surrounded by a hummocky relief (Fig. 11).

There is ample evidence for periglacial conditions in the Alpine foreland during the late glacial such as the development of thick periglacial cover-beds and solifluction movement (e.g. Jerz 1970b; Semmel, 1973; MAIlÄNDER \& VeIt 2001; BusSEMER 2002/03), evidence for dead ice bodies in the moraines (GRUBE 1983; BuSSEMER 2002/03), periglacially developed Buckelfluren (a special form of hummocky relief) (JeRZ et al. 1966; ENGELSCHALK 1971) and frost-wedges (JERZ et al. 1966; Menzies \& HABBe 1992; Bussemer 2002/03).

The time period of the Eastern Alpine deglaciation was punctuated by different cold events which correlate with phases of colder sea surface temperatures in the North Atlantic (Heinrich-events; Bond et al. 1997). VoN GrAfENSTEIN (1999) showed that these late glacial cold events are very well documented in the $\delta^{18} \mathrm{O}_{\mathrm{p}}$-record of the Ammersee in close proximity to the sampling sites on the Würmian moraines (Fig. 7). Furthermore, the late glacial Gschnitz advance $(15.4 \pm 1.8 \mathrm{ka})$ in the Eastern Alps, that is tentatively correlated with $\mathrm{H} 1$, shows that the atmospherically transported $\left(\delta^{18} \mathrm{O}_{\mathrm{p}}\right)$ cold pulses from the North Atlantic triggered glacial advances in the Alps (IvY-OcHs et al. 2006a and references therein). Consequently, climatic conditions during $\mathrm{H} 1$ may have been favorable for periglacial activity on the Alpine foreland that could result in boulder exhumation by slope processes throughout the late glacial.

However, one could reason that there could be another explanation for the measured age distribution. One explanation for 'too young' exposure ages measured in erratics on the Alpine foreland moraines is quarrying of boulders by humans for which there is evidence since Neolithic times (e.g. ZEHENDNER 1986), and is still ongoing today (gravestones, monuments). However, no obvious signs of quarrying were observed on the sampled boulder surfaces. Smooth boulder surfaces as well as protruding quartz veins indicate that no anthropogenic chipping occurred. Furthermore, the exposure ages of an extensively quarried boulder would be expected to be much younger than the observed ages or scatter considerably more.

Another explanation for the age distribution could be tilting or toppling of the boulders possibly caused by falling trees. Boulder movement can explain a large spread in ages and cause exposure ages being younger than the landform (CERLING \& CRAIG 1994). However, toppling of boulders caused by trees is more likely to occur during the Holocene, when dense forests covered the study area. The absence of Holocene outliers renders this explanation of the age distribution unlikely. 


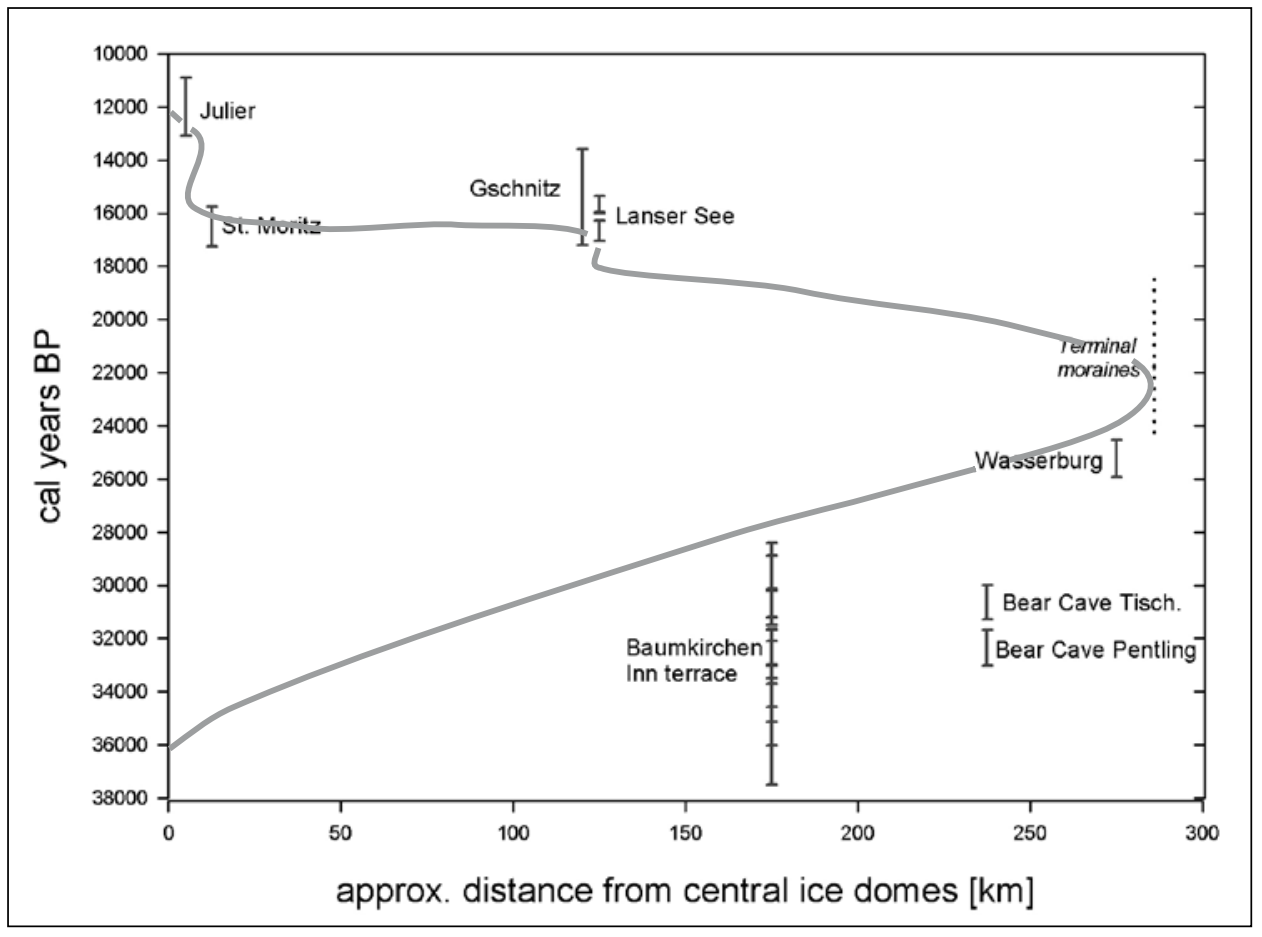

Fig. 10: Schematic time-distance diagram of ice-advance of the Inn glacier based on published radiocarbon, luminescence and exposure ages. The reported ages are taken from KNEUSSL (1972, 1973), FLIRI (1973), BORTENSCHLAGER et al. (1978), SUTER (1981), BORTENSCHLAGER (1984a, b), HABBE et al. (1996), IVY-OCHS et al. (2006a, b).

Abb. 10: Schematisches Zeit-Entfernungsdiagramm der Eisvorstöße des Inngletschers basierend auf publizierten Radiokohlenstoff-, Lumineszenzund Expositionsalterdatierungen. Die Alter stammen aus: KNEUSSL (1972, 1973), FLIRI (1973), BORTENSCHLAGER et al. (1978), SUTER (1981), BORTENSCHLAGER (1984a, b), HABBE et al. (1996), IVY-OCHS et al. (2006a, b).

Chipping of the surface or toppling of boulders is not suited to convincingly explain the exposure age distribution measured in the study area. We therefore interpret the age distribution as indicative for a glacial environment with persistent dead ice in the moraines, periglacial slope processes that might have exhumed boulders until final moraine stabilization in the late glacial.

\section{Discussion of results with respect to the two different glacial environments}

We have presented and discussed the results of two new exposure dating studies in south-eastern Germany based on the profound work of REUTHER (2007). Dating of moraine boulders of the maximum Würmian ice extent in two different glacial environments has shown that the age distributions determined in the two study areas are very different (Fig. 12) despite the similarity of the climatic boundary conditions.

A consistent and precise late Würmian chronostratigraphy was derived from moraines and bedrock surfaces in the catchment of a small valley glacier in the Bavarian Forest. Its initial ice advance occurred shortly before $20.7 \pm 2.0 \mathrm{ka}$. The glacier deposited two distinct lateral moraines in a time period of 2-3 ka of glacier oscillation around 18-19 ka. A first recessional moraine was deposited at $17.3 \pm 1.6 \mathrm{ka}$ and a late glacial readvance occurred around $15.5 \pm 1.6 \mathrm{ka}$. The glacier melted back into its cirque location after $14.5 \pm 1.8 \mathrm{ka}$. The exposure ages are consistent with bracketing radiocarbon ages (RAAB \& VÖLKEL 2003).

The exposure age distribution from terminal moraines of the Isar-Loisach and the Inn glacier indicate a moraine deposition well before $18.0 \pm 1.9 \mathrm{ka}$, and a phase of moraine stabilization throughout the late glacial as implied by an older age cluster around $18.0 \pm 1.9 \mathrm{ka}$ and a spread toward younger ages. Late glacial readvances in the Eastern Alps occurred after the piedmont lobes and interconnected valley glaciers had melted back into the steep tributary valleys forming a dendritic valley glacier system (REITNER 2007). Two distinct late glacial readvances in the Eastern Alps were the Gschnitz advance $(\sim \mathrm{H} 1$ cold event) and the Egesen advance ( Younger Dryas cold event) of which moraines are only preserved in small to medium size catchments of the Eastern Alps (IvyOcHs et al. 2006a, b). Both glacial advances have been exposure dated by others; the Gschnitz advance to about $15.5 \pm 1.8 \mathrm{ka}$ (Ivy-Ochs et al. 2006a) and the Egesen advance to about $12.2 \pm 1.1 \mathrm{ka}$ (Ivy-OcHs et al. 2006b).

Our results show that both glacial systems reached their maximum Würmian ice extent during the late Würmian (marine isotope stage 2; Fig. 12), supporting our basic assumption that the general circulation and climatic pattern in the two study areas were similar. Despite the broad synchronicity, the response time to climatic fluctuations of a small valley glacier in comparison to the response time of an extensive ice cap and piedmont glacier system is very different; with the small valley glacier in the Bavarian Forest being more sensitive to climatic signals. The synchronicity of the late glacial readvance in the Bavarian Forest (lake moraine) and the Eastern Alps (Gschnitz advance) around 16-15 ka ago suggests that phases of colder climates around the North Atlantic lead to glacier advances of small valley glaciers of the Bavarian Forest at the same time as the small tributary valley glaciers of the Eastern Alps advanced. Consequently, we attribute the differences in the age distributions determined on the respective terminal moraines to geomorphic processes affecting moraine stabilization differently in the two glacial environments.

Moraines deposited by the small valley glacier in the Kleiner Arbersee catchment stabilized shortly after the glacier abandoned the moraines. The fast slope stabilization is portrayed by the precise and coherent exposure age distribution on the moraines. The moraine morphology shows no signs for thawing of dead ice, and the moraine boulders are too tall and massive (Tab. 1) for exhumation during post- 


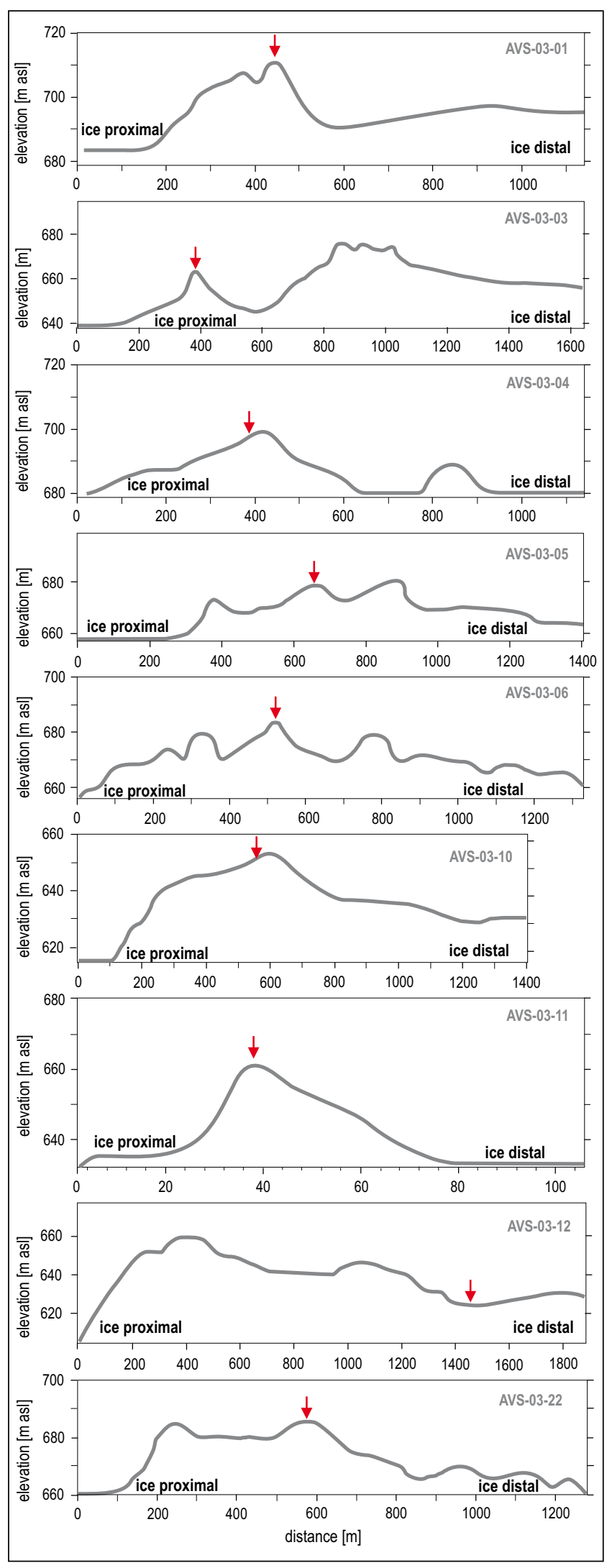

Fig. 11: Cross sections through the terminal moraine complex of the IsarLoisach glacier at the sampling locations, showing the obvious hummocky relief and kettle holes. The red arrows mark the location of the sampled boulders. The cross sections cut the moraine wall radially. (Interpolated from the 1:5,000 contour line maps, $10 x$ vertically exaggerated).

Abb. 11: Querschnitt durch den Endmoränenkomplex des Isar-Loisach Gletschers an den Probennahmestellen zeigen ein deutliches kuppiges Relief mit Toteislöchern. Der rote Pfeil markiert die Position des geprobten Findlings. Die Querschnitte schneiden die Moränen radial (Interpolation von 1:5.000 Höhenlinienkarten, 10fach vertikale Überhöhung). depositional moraine degradation by periglacial slope processes. This relative landform stability is likely the reason for the coherent chronology.

In contrast, the surface topography of the moraines on the Alpine foreland (Fig. 8, 11) suggests that the landscape did not stabilize rapidly after the glaciers were cut off from their accumulation areas. Dead ice bodies likely prevailed until well after deglaciation of the region when periglacial activity ceased and the climate ameliorated. The age distribution measured in boulder surfaces from these moraines covers the entire late glacial. Moraine stabilization was not a function of the paleogeographic position, such as that the outer moraines stabilized first. The moraine boulders that yield the oldest ages are located on high moraine ridges with less evidence for thawing of dead ice, whereas the younger boulders are located on smaller ridges, surrounded by hummocky relief that implies delayed thawing of dead ice (e.g., GRIPP \& EBERS 1957). We therefore interpret the age distribution as indicative of a time period of melting of dead ice in the late glacial following the deposition of the set of terminal moraines. Furthermore, the boulders that were preserved on the moraines of the Alpine glaciers were relatively small in size (Tab. 2), some might have been exhumed after the initial moraine deposition during a phase of moraine degradation.

The deglaciation of the small valley glacier in the Bavarian Forest (2.5 km terminal moraine - cirque backwall) occurred by melting back of the glacier front at a slow and steady rate punctuated only by minor glacier oscillations. This slow melting reflects a rise of the glacial equilibrium line altitude (ELA) in the fairly steep Seebach valley under ameliorating climatic conditions in the late glacial. The readvance to the lake moraine occurred during a late glacial cold event, around the same time as the Gschnitz advance in the Alps.

In contrast, the rise of the ELA of the Eastern Alpine glaciers during deglaciation turned the piedmont lobes on the alpine foreland and in the low relief major valleys into stagnant ice masses (vAN HUSEN 1987). The nested terminal moraines of the maximum alpine ice advance were deposited by the large piedmont lobes extending over $200 \mathrm{~km}$ from the accumulation area to the north onto the flat foreland. The large ice masses did not react sensitively to shortlived climatic events. Only after they had melted back and formed separate valley glaciers during the late glacial, cold events are represented by moraines.

The two different data sets give insight into landscape stability and moraine degradation in different glacial environments and have important implications for sampling strategies for exposure dating studies on moraines.

Our results support preliminary studies that showed that precise exposure ages are not randomly distributed among moraines from all glacier types (REuTHER et al. 2006). Small valley glaciers respond fairly rapidly to climatic changes and therefore a moraine can be deposited and stabilized in a short time period $\left(\sim 10^{2}\right.$ years). As a result moraines located in small alpine valleys with fairly simple moraine morphology may yield precise exposure ages (e.g. Gosse et al. 1995a, b; Ivy-Ochs et al. 1996, 1999; Owen et al. 2003; VÁzQuez-SELEM đ̛ HeINE 2004).

In contrast, piedmont ice lobes or ice sheets that extend 


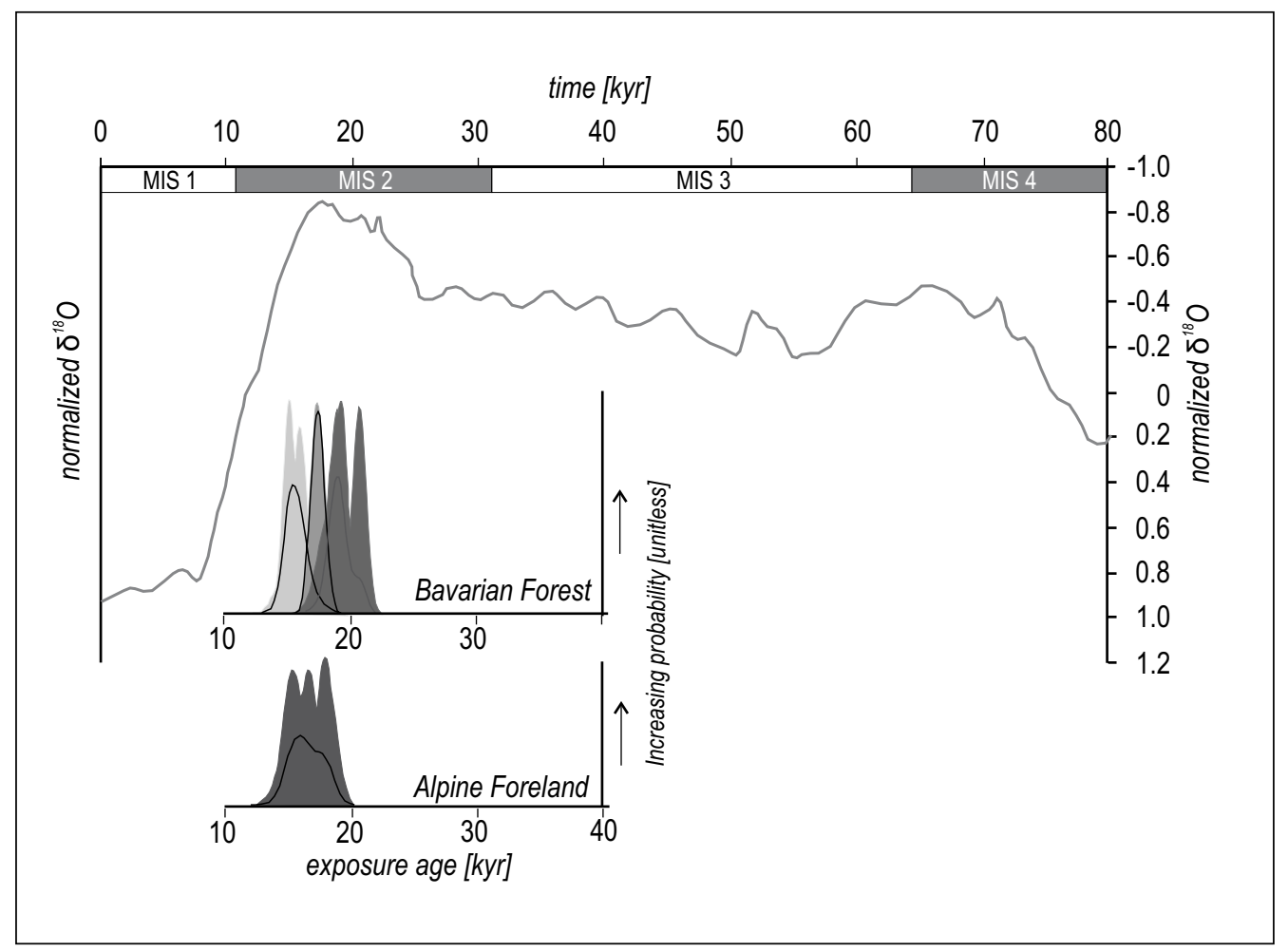

Fig. 12: Probability density diagrams of the exposure ages from the two study areas plotted against the $\delta^{18} \mathrm{O}$ deep-sea North Atlantic Specmap curve (MARTINSON et al. 1987). The dark grey density functions show the outline of the exposure age distribution from all exposure ages measured on the respective terminal moraines in both study areas. The lighter grey age distribution outlines are from the ages measured on the recessional moraines in the Bavarian Forest. The solid dark line under the outline of the probability density functions (PDF) shows the sum of all PDFs from one moraine.

Abb. 12: Wahrscheinlichkeitsdichtediagramm der Expositionsalter der beiden Untersuchungsgebiete dargestellt gegen die $\delta^{18} \mathrm{O}$-Tiefsee-Specmap-Kurven aus dem Nordatlantik (MARTINSON et al. 1987). Die dunkelgrauen Dichtefunktionen zeigen die Außenlinie der Expositionsalter-Verteilungen aller Alter, die auf den Endmoräne in beiden Untersuchungsgebieten gemessen wurden. Die hellgrauen Altersverteilungen zeigen die Alter, die auf den Rückzugsmoränen im Bayerischen Wald gemessen wurden. Die durchgezogene dunkle Linie beschreibt die Wahrscheinlichkeitsdichtefunktion der Summe aller Wahrscheinlichkeitsdichtefunktionen von den jeweiligen Moränen.

a few hundred kilometres from the accumulation area with a thickness of hundreds of meters will take much longer to arrive at equilibrium with the climatic conditions and may fluctuate for thousands of years around their maximum position and possibly disconnect large dead ice bodies (GRIPP 1929; Owen et al. 2001; BenN \& OwEN 2002; BoWEN et al. 2002). As a result, datasets from extensive piedmont lobe moraines with prominent (push-) moraines over wide foreland areas show considerably more scatter in ages (see above and also Ivy-OcHs et al. 2004) reflecting their more complex deglaciation history. Ice cored moraines will not stabilize before the melting of the ice core. Exposure dates of moraine boulders on moraine series deposited by an extensive piedmont lobe could give similar age ranges and the ages would have no geographical meaning in the sense of recessional moraines. Glacial deposits from large ice sheet margins similarly show some scatter in exposure ages (e.g. LiCCIARDi et al. 2001; BALCo et al. 2002; Bowen et al. 2002; LANDVIK et al. 2003; RiNTERKNECHT et al. 2006). The only way to minimize the effect of exhumation of boulders during moraine stabilization is to sample tall and massive boulders.

Even though the described processes complicate data interpretation for moraine dating studies, this methodological challenge might open new avenues for determin- ing phases of intensive slope processes on moraine and thawing of dead ice during which boulders were exhumed. Exposure dating in extra-glacial terrains has already been successfully used to constrain times of intensive periglacial activity in Australia (BARRows et al, 2004).

\section{Summary and Outlook}

The findings from this study can be grouped into three categories:

(1) Surface exposure ages from the catchment of the Kleiner Arbersee glacier yield a consistent and precise late Würmian local stratigraphy. The exposure ages are in agreement with the few published radiocarbon ages from the study area.

The initial glacial advance of the Kleiner Arbersee glacier occurred just before $20.7 \pm 2.0 \mathrm{ka}$. During the following $2-3 \mathrm{ka}$, the glacier deposited two distinct lateral moraines that form a set of terminal moraines. The outer ridge stabilized around $19.1 \pm 2.0 \mathrm{ka}$, the inner ridge stabilized at $18.7 \pm 1.9 \mathrm{ka}$. A first recessional moraine was deposited at $17.3 \pm 1.6 \mathrm{ka}$; a late glacial readvance occurred around $15.5 \pm 1.7 \mathrm{ka}$. The glacier melted back into its cirque location after $14.5 \pm 1.8 \mathrm{ka}$.

The exposure age distribution shows an insignificant scatter, so that precise moraine ages were derived, despite 
the dense forest cover in the study area. Even the deposition times of two ridges of a double-crested terminal moraine within $3 \mathrm{ka}$ could be resolved. The moraines were not overprinted by post-depositional moraine degradation due to thawing of dead ice. This stability of the moraines is likely the reason for the precise exposure ages.

The local glacial chronology of the Kleiner Arbersee catchment indicates that the late Würmian glaciation was broadly synchronous with that of the Eastern Alps as implied by the late glacial advance around 16-15 ka. Consequently, the phases of 'glacier-friendly' climates during the late Würmian affected the small glaciers of the Bavarian Forest similarly as they affected the Eastern Alpine glaciers.

(2) Surface exposure ages from the type section of the Würm glaciation, the Würmsee area, show that maximum terminal moraines of the Isar-Loisach glacier and the Inn glacier were deposited during the late Würmian (MIS 2). The exposure ages, however, do not reflect the exact time of moraine deposition. Instead the age distribution, after exclusion of outliers, shows an older age cluster around $18 \mathrm{ka}$ and a tailing out towards young ages. This age range is interpreted as indicative of a time of intensive moraine degradation due to melting of dead ice or periglacial slope processes that might have exhumed boulders from the moraine matrix during the late glacial $(18-15 \mathrm{ka})$. There is ample independent evidence from the study area for intensive late glacial periglacial morphodynamic that could explain the slope processes from the terminal moraines on the Alpine foreland. The moraine boulders that yield the oldest ages are located on high moraine ridges, whereas the younger boulders are located on smaller ridges, surrounded by hummocky relief. The youngest boulder is located at the proximal side of the moraines in a former meltwater channel and was probably not exhumed before the end of the Pleistocene.

(3) The results of this study demonstrate again the great potential but also the pitfalls of surface exposure dating for establishing precise glacial chronologies from terrestrial records. Even though recent efforts have reduced the analytical and systematic errors of TCND, moraine ages often show more scatter than expected from the reported errors. The most important uncertainties in moraine dating are caused by geomorphological processes and thawing of dead ice.

The exposure ages from the two study areas prove that precise exposure ages are more likely determined from large boulders on well-preserved moraines, deposited by small valley glaciers. In contrast, the persistence of dead ice and prevailing of periglacial activity following deglaciation likely result in a post-depositional moraine degradation and exhumation of boulders resulting in exposure ages that scatter widely.

Moraine boulder ages do not only depend on the deposition of the landform but also on its erosion history. Landform degradation is considerable and operates on time scales that significantly interfere with the resolution of TCND that are routinely used to determine the ages of boulders on landforms comprised of unconsolidated materials. However, rates of moraine degradation are not uniform; they depend on the sedimentary composition of the moraine matrix material, the glacial environment, the presence of dead ice and on the climatic boundary conditions. Therefore, each data set and even each boulder exposure age has to be interpreted individually on the background of the relevant processes and the deposition environment. In any case the boulder age does not equate the age of the moraine, but the time of boulder stabilization.

Further refinement in moraine dating with TCND will only be possible if rates and timing of geomorphologic processes that result in moraine degradation can be better constrained.

\section{Acknowledgements}

We thank H. Schmid (Bavarian Geological Survey) for helping to obtain sampling permission from the Regierung der Oberpfalz (erratics of the Bavarian Forest) and the Untere Naturschutzbehörden (natural heritage erratics of the Alpine foreland) and members of many authorities for their assistance. We sincerely thank the Zürich AMS facility for laboratory facilities. The authors thank I. Hajdas and an anonymous reviewer for suggestions of how to improve the manuscript. The research was funded by the Deutsche Forschungsgemeinschaft (DFG-Az.: He 722/32-1 and 2).

\section{References}

Attmannspacher, W. (ed.) (1981): 200 Jahre meteorologische Beobachtungen auf dem Hohenpeißenberg 1781-1980. - Berichte des Deutschen Wetterdienstes, 155: 84.

Balco, G., Stone, J. O., Porter, S. C. \& Caffee, M. W. (2002): Cosmogenic-nuclide ages for New England costal moraines, Martha's Vineyard and Cape Cod, Massachusetts, USA. - Quaternary Science Reviews, 21: 2127-2135.

Barrows, T., Stone, J. \& Fifield, L. K. (2004): Exposure ages for Pleistocene periglacial deposits in Australia. - Quaternary Science Reviews, 23: 697-708

BAumgartner, A. (1970): Klima und Erholung im Bayerischen Wald. - In Makowsky, H. \& WeinzierL, H. (eds.): Natur, Freizeit und Erholung. Verhandlungen Deutscher Beauftragter für Naturschutz und Landschaftspflege, 17: 39-53.

BAYBERgER, F. (1886): Geographisch-geologische Studien aus dem Böhmerwalde. Die Spuren alter Gletscher, die Seen und Thäler des Böhmerwaldes. Petermann Geographische Mitteilungen 81. - 63 S.; Stuttgart (Klett).

BEck, P. (1932): Über den eiszeitlichen Aaregletscher und die Quartärchronologie. - Verein der Naturforschenden Gesellschaft Thun, 113: 343-359.

BENN, D. I. \& OWEN, L. A. (2002): Himalayan glacial sedimentary environments: a framework for reconstructing and dating the former extent of glaciers in high mountains. - Quaternary International, 97-98: 3-25.

Beug, H. J. (1976): Die spätglaziale und frühpostglaziale Vegetationsgeschichte im Gebiet des ehemaligen Rosenheimer Sees, Oberbayern. Botanische Jahrbücher für Systematik, Pflanzengeschichte und Pflanzengeographie, 95: 373-400.

Bludau, W. \& Feldmann, L. (1994): Geologische, geomorphologische und pollenanalytische Untersuchungen zum Toteisproblem im Bereich der Osterseen südlich von Seeshaupt (Starnberger See). - Eiszeitalter und Gegenwart, 44: 114-128.

Bond, G., Showers, W., Cheseby, M., Lotti, R., Almasi, P., DeMenocal, P., Priore, P., Cullen, H., Hajdas, I. \& Bonani, G. (1997): A pervasive millennial-scale cycle in North Atlantic Holocene and glacial climates. - Science, 278: 1257-1266.

Bortenschlager, S. (1984a): Die Vegetationsentwicklung im Spätglazial: Das Moor beim Lanser See III, ein Typprofil für die Ostalpen. - Dissertationae Botanicae, 72 (Festschrift Welten): 71-79.

Bortenschlager, S. (1984b): Die Beiträge zur Vegetationsgeschichte Tirols I. Inneres Ötztal und unteres Inntal. - Berichte des naturwissenschaftlich-medizinischen Vereins Innsbruck, Innsbruck, 71:19-56. 
Bortenschlager, S., Fliri, F., Heuberger, H \& Patzelt, G. (1978): Innsbrucker Raum und Ötztal. - Führer zur Tirol-Exkursion anlässlich der 19. wissenschaftlichen Tagung der Deutschen Quartärvereinigung 1978 in Wien. Innsbruck, 36 S.

Bowen, D. Q., Phillips, F. M., McCabe, A. M., Kuntz, P. C. \& Sykes, G. A. (2002): New data for the Last Glacial Maximum in Great Britain and Ireland. - Quaternary Science Reviews, 21: 89-101.

Briner, J. P., Kaufman, D. S., Manley, W. F., Finkel, R. C. \& Caffee, M. C. (2005): Cosmogenic exposure dating of late Pleistocene moraine stabilization in Alaska. - Geological Society of America Bulletin, 117 1108-1120.

BRonk RAmSEy, C. (2009): Bayesian analysis of radiocarbon dates. - Radiocarbon, 51(1), 337-360.

Bucher, M. (1999): Der glaziale Formenschatz im Gebiet um den Kleinen Arbersee (Bayerischer Wald, Deutschland). - Zeitschrift für Geomorphologie NF, Suppl.-Vol. 113: 45-58.

Bussemer, S. (2002/03):. Periglaziale Deckschichten und Bodenmosaike der Jungmoränenlandschaften von Oberbayern und Nordtirol. - Mitteilung der Geographischen Gesellschaft München, 86: 17-58.

CANnell, M. G. R. (1982): World forest biomass and primary production data. - 391 S.; London (Academic Press).

Cerling, T. E. \& Craig, H. (1994): Geomorphology and in-situ cosmogenic isotopes. - Annual Reviews of Planetary Sciences, 22: 273-317.

Chaline, J. \& Jerz, H. (1984): Arbeitsergebnisse der Subkommission für Europäische Quartärstratigraphie. Stratotypen des Würm-Glazials. Eiszeitalter und Gegenwart, 35: 185-206.

Cockburn, H. \& Summerfield, M. (2004): Geomorphological applications of cosmogenic isotope analysis. - Progress in Physical Geography, 28: 1-42.

Dietrich, H.-P., Raspe, S., Schwarzmeier, M. \& Ilg, S. (2002): Biomasseund Nährstoffinventuren zur Ermittlung von Ernteentzügen an drei bayerischen Fichtenstandorten. - In: Dietrich, H.-P., RASPE, S. \& Preusler, T. (eds.): Inventur von Biomasse- und Nährstoffvorräten in Waldbeständen: 59-72; Forstliche Forschungsberichte, München (Wissenschaftszentrum Weihenstephan).

Dreesbach, R. (1985): Sedimentpetrographische Untersuchungen zur Stratigraphie des Würmglazials im Bereich des Isar-Loisach-Gletschers. - Dissertation, University of Munich, $176 \mathrm{~S}$.

DunNe, J., Elmore, D. \& Muzikar, P. (1999): Scaling factors for the rates of production of cosmogenic nuclides for geometric shielding and attenuation at depth of sloped surfaces. - Geomorphology, 27: 3-11.

Dyke, A. S. \& SAVelle, J. M. (2000) : Major end moraines of Younger Dryas age on Wollaston Peninsula, Victoria Island, Canadian Arctic: implications for paleoclimate and for formation of hummocky-moraine. Canadian Journal of Earth Sciences, 37: 601-619.

Ehlers, J. \& GibBARD, P. L. (eds.), (2004a): Quaternary Glaciations - Extent and Chronology, Part I: 475 S.; Amsterdam (Elsevier).

Ehlers, J. \& GibBARD, P. L. (eds.), (2004b): Quaternary Glaciations - Extent and Chronology, Part I: Digital data on CD; Amsterdam (Elsevier).

Ehlers, J., Eissmann, L., Lippstreu, L., Stephan, H. J. \& WANSA, S. (2004) Pleistocene glaciations of Northern Germany. - In: EHLERS, J. \& GibBARD, P. (eds.): Quaternary Glaciations - Extent and Chronology, Part I: 135-146; Amsterdam (Elsevier).

EngelschalK, W. (1971): Alpine Buckelfluren. - Regensburger Geographische Schriften 1: 159 S.; Regensburg (Institut für Geographie).

Ergenzinger, P. (1967): Die eiszeitliche Vergletscherung des Bayerischen Waldes. - Eiszeitalter und Gegenwart, 18: 152-168.

Evans, D. J. A. ( ed.), (2004): Glacial landsystems. - 532 S.; London (Arnold).

Everest, J. \& Bradwell, T. (2003): Buried glacier ice in southern Iceland and its wider significance. - Geomorphology, 52: 347-358.

Feldmann, L. (1992): Ehemalige Ammerseestände im Hoch- und Spätglazial des Würm. - Eiszeitalter und Gegenwart, 42: 52-61.

FeldmanN, L. (1998): Der würmzeitliche Isar-Loisachgletscher. - GeoArchaeoRhein, 2: 103-120.

Fiebig, M., Buiter, S. J. H. \& Ellwanger, D. (2004):. Pleistocene glaciations of South Germany. - In: Ehlers, J. \& GibBARD, P. L., (eds.): Quaternary Glaciations - Extent and Chronology, Part I: 145-154; Amsterdam (Elsevier)

Fitzsimons, S. J. (1996): Paraglacial redistribution of glacial sediments in the Vestfold Hills, East Antarctica. - Geomorphology, 15: 93-108.

FLIRI, F. (1973): Beiträge zur Geschichte der alpinen Würmvereisung: Forschungen am Bänderton von Baumkirchen (Inntal, Nordtirol). Zeitschrift für Geomorphologie NF, Suppl.-Vol. 16: 1-14.

Florineth, D. \& SCHLÜCHTER, C. (1998): Reconstructing the Last Glacial Maximum (LGM) ice surface geometry and flowlines in the Central Swiss Alps. - Eclogae Geologicae Helveticae, 91: 391-407.
FloRineth, D. (1998): Surface geometry of the Last Glacial Maximum (LGM) in the southeastern Swiss Alps (Graubünden) and its paleoclimatological significance. - Eiszeitalter und Gegenwart, 48: 23-37.

FrAnk, H. (1979): Glazial übertiefte Täler im Bereich des Isar-LoisachGletschers. - Eiszeitalter und Gegenwart, 29: 77-99.

FURRER, G. (1991): 25.000 Jahre Gletschergeschichte dargestellt an einigen Beispielen aus den Schweizer Alpen. - Verein der Naturforschenden Gesellschaft Zürich Neujahrsblatt, 193, Zürich, 52 S.

Geyh, M. A. \& Schreiner, A. (1984): ${ }^{14} \mathrm{C}$-Datierungen an Knochen und Stoßzahn Fragmenten aus würmzeitlichen Ablagerungen im westlichen Rheingletschergebiet (Baden-Württemberg). - Eiszeitalter und Gegenwart, 34: 155-151.

Gosse, J. C. \& Phillips, F. M. (2001): Terrestrial in situ cosmogenic nuclides: theory and application. Quaternary Science Reviews, 20: $1475-1560$.

Graul, H. (1957): Sind die Jungendmoränen im nördlichen Alpenvorland gleichaltrig? - Petermanns Geographische Mitteilungen Ergänzungsheft, 262 (Machatschek-Festschrift): 209-212.

Gosse, J. C., Evenson, E. B., Klein, J., Lawn, B. \& Middleton, R. (1995b) Precise cosmogenic ${ }^{10} \mathrm{Be}$ measurements in western North America: Support for a global Younger Dryas cooling event. - Geology, 23: 877-880.

Gosse, J. C., Klein, J., Evenson, E. B., Lawn, B. \& Middleton, R. (1995a): Beryllium-10 Dating of the duration and retreat of the Last Pinedale Glacial Sequence. - Science, 268: 1329-1333.

GRIPP, K. (1929): Glaciologische und geologische Ergebnisse der Hamburgischen Spitzbergen Expedition 1927. - Abhandlungen des Naturwissenschaftlichen Vereins zu Hamburg, Hamburg, 249 S.

GrIPP. K. \& EBERs, E. (1957): Die Grenze von Inn- und Chiemseegletscher und die glazialmorphologische Kartenanalyse. - Petermanns Geographische Mitteilungen Ergänzungsheft, 262 (Machatschek-Festschrift): 227-239.

GrubE, F. (1983): Morphologie der äußeren Würmvergletscherung in der Typusregion südlich München. - In: Führer zu den Exkursionen der Subkommission für Europäische Quartärstratigraphie vom 13.-20.09.1983. München: 13-16.

HabBe, K. A., Jerz, H. \& Doppler, G. (1996): Schieferkohlen bei Wasserburg am Inn. - Exkursionsführer DEUQUA 15.-16.09.1996. Gmunden/ Oberösterreich: $32 \mathrm{~S}$

Hallet, B. \& Putkonen, J. (1994): Surface dating of dynamic landforms: Young boulders on aging moraines. - Science, 265: 937-940.

HantKe, R. (1980): Eiszeitalter. Die jüngste Erdgeschichte der Schweiz und ihrer Nachbargebiete. Band 2. - 703 S.; Thun (Ott).

HAUnER, U. (1980): Untersuchungen zur klimagesteuerten tertiären und quartiären Morphogenese des Inneren Bayerischen Waldes, RachelLusen, unter besonderer Berücksichtigung pleistozän kaltzeitlicher Formen. Nationalpark Bayerischer Wald. - Schriftenreihe Bayerisches Staatsministerium Ernährung, Landwirtschaft und Forsten, 6 198 S.; München.

HAuner, U. (1998): „Geowissenschaftliche Projekte aus Ostbayern im Erdkundeunterricht" Projekt II: Pleistozäne Formen und Ablagerungen im Inneren Bayerischen Wald. - In: Hartl, M. \& Huber, M. (eds.) Regensburg und Ostbayern mit Nachbarregionen - geographische Streifzüge: 94-99; München (Pfeil).

Heim, A. (1885): Handbuch der Gletscherkunde. - 560 S.; Stuttgart (Engelhorn)

HeIne, K. (2011): Late Quaternary glaciations in Bolivia: Comments on some new approaches to dating morainic sequences. - In: EHLERS, J., Gibbard, P. \& Hughes, P.D. (eds.): Quaternary Glaciations - Extent and Chronology, Part IV - A Closer Look: xxx-xxx; Amsterdam (Elsevier).

Heine, K., Reuther, A. U., Thieke, H. U., Schulz, R., Schlaak, N. \& KuBIK, P. W. ( 2009): Timing of Weichselian ice marginal positions in Brandenburg (northeastern Germany) using cosmogenic in situ ${ }^{10} \mathrm{Be}$. - Zeitschrift für Geomorphologie N.F, 53: 433-454.

HöGGERL, N. (1989): Rezente Höhenänderungen in Ósterreich abgeleitet aus Präzisionsnivellement-Messungen. - In: Lichtenegger H, STEINHAUSER P. \& SüNKEL H. ( eds.): Tagungsbericht 5. Internationales Alpengravimetrie-Kolloquium Graz 1989, Österreichische Beiträge zur Meteorologie und Geophysik, 2:161-173.

Hormann, K. (1974): Ein neues Modell des würmzeitlichen Inn-Chiem see-Gletschers - Überschiebungen des Inngletschers über den Tiroler Achengletscher bis in die Bereiche des heutigen Chiemsees. - Eiszeitalter und Gegenwart, 25: 35-47.

Ivy-Ochs, S. (1996): The dating of rocksurfaces in situ produced ${ }^{10} \mathrm{Be},{ }^{26} \mathrm{Al}$ and ${ }^{36} \mathrm{Cl}$ with examples from Antarctica and the Swiss Alps. - PhD Thesis No 11763, ETH Zürich, 196 S. 
Ivy-Ochs, S., Kerschner, H., KubIK, P.W. \& Schlüchter, C. (2006a): Glacier response in the European Alps to Heinrich event 1 cooling: the Gschnitz stadial. - Journal Quaternary Science, 21: 115-130.

Ivy-Ochs, S., Kerschner, H., Reuther, A., Schäfer, J., Kubik, P. W., MaIsch, M. \& SchlÜChteR, C. (2006b): The timing of glaciations in the European Alps based on surface exposure dating with cosmogenic ${ }^{10} \mathrm{Be},{ }^{26} \mathrm{Al},{ }^{36} \mathrm{Cl}$, and ${ }^{21} \mathrm{Ne}$. - In: Siame, L. L., Bourles, D. L. \& Brown, E. T. (eds.): In Situ Cosmogenic Nuclides and their Applications in Earth Sciences. Geological Society of America Special Paper, 415: 43-60.

Ivy-Ochs, S., Kerschner, H., Reuther, A., Preusser, F., Heine, K., Maisch, M., Kubik, P.W. \& SchlÜchter, C. (2008): Chronology of the last glacial cycle in the European Alps. - Journal Quaternary Science, 23: 559-573.

Ivy-Ochs, S., Schäfer, J., Kubik, P. W., Synal, H-A. \& Schlüchter, C. (2004): Timing of deglaciation on the northern Alpine Foreland (Switzerland). - Eclogae Geologicae Helveticae, 97: 47-55.

Ivy-Ochs, S., Schlüchter, C., KubIK, P. W. ¿ Denton, G. H. (1999): Moraine exposure dates imply synchronous Younger Dryas glacier advances in the European Alps and in the southern Alps of New Zealand. - Geografiska Annaler A, 81: 313-323.

Ivy-Ochs, S., Schlüchter, C., Kubik, P. W., SynAl, H.-A. \& Kerschner, H. (1996): The exposure age of an Egesen moraine at Julier Pass, Switzerland, measured with the cosmogenic radionuclides ${ }^{10} \mathrm{Be},{ }^{26} \mathrm{Al}$ and ${ }^{36} \mathrm{Cl}$. - Eclogae Geologicae Helveticae, 89: 1049-1063.

JÄCKLI, A. (1970): Die Schweiz zur letzten Eiszeit: Atlas der Schweiz 6. Eidgenössische Landestopographie. Wabern-Bern.

JERZ, H. (1970a): Eisrandlagen und Oszillationen des würmzeitlichen Innvorlandgletschers. - Zeitschrift der Deutscben Geologischen Gesellschaft, 120: 13-22.

JeRZ, H. (1970b): Zur Stratigraphie des Jungquartärs im nördlichen Alpenvorland nach ${ }^{14} \mathrm{C}$-Datierungen. - Geologica Bavarica, 63: 207-216.

Jerz, H. (1979): Das Wolfratshausener Becken seine glaziale Anlage und Übertiefung. - Eiszeitalter und Gegenwart, 29: 63-69.

JERZ, H. (1987a): Erläuterungen zur Geologischen Karte von Bayern 1:25,000 zum Blatt Nr. 8034 Starnberg Süd: 173 S.; München (Bayerisches Geologisches Landesamt).

Jerz, H. (1987b): Erläuterungen zur Geologischen Karte von Bayern 1:25,000 zum Blatt Nr. 7934 Starnberg Nord: 128 S.; München (Bayerisches Geologisches Landesamt).

Jerz, H. (1993): Das Eiszeitalter in Bayern - Geologie von Bayern II. - 243 S.; Stuttgart ( Schweizerbart)

Jerz, H. \& UlRICH, R.(1983): Das Schieferkohlevorkommen von Herrnhausen südlich von Wolfratshausen. - Geologica Bavarica, 84: 101-106.

Jerz, H., Ulrich, R., Vidal, H. \& Hohenstatter, E. (1966): Erläuterungen zur Geologischen Karte von Bayern 1:25 000, Blatt 8533/8633 Mittenwald: 152 S.+ map; München (Bayerisches Geologisches Landesamt).

Kelly, M. A., Buoncristiani, J.F. \& Schlüchter, C. (2004): A reconstruction of the last glacial maximum (LGM) ice-surface geometry in the western Swiss Alps and contiguous Alpine regions in Italy and France. - Eclogae Geologicae Helveticae, 97: 57-75.

Kerschner, H. (1996): Multivariate statistical modelling of equilibrium line altitudes: Hintereisferner (Ötztal) - Stubacher Sonnblickkees (Hohe Tauern). - Zeitschrift für Gletscherkunde und Glazialgeologie, 32: 119-127.

Kerschner, H., Ivy-Ochs, S. \& Schlüchter, C. ( 2008): Gletscher und Klima im Ostalpenraum zwischen 16.000 und 11.000 Jahren vor heute. - Abhandlungen der Geologischen Bundesanstalt, 62: 165-168.

Kleinmann, A. (1995): Seespiegelschwankungen am Ammersee. Ein Beitrag zur spät- und postglazialen Klimageschichte Bayerns. - Geologica Bavarica, 99: 253-367.

KNEussL, W. (1972): Vorbericht über eine Grabung in der Bärenhöhle am Pendling bei Kufstein (Nordtirol). - Zeitschrift für Gletscherkunde und Glazialgeologie, 8: 329-330.

KnEussL, W. (1973): Höhlenbärenknochen aus der Tischofer-Höhle (Kaisertal bei Kufstein - Nordtirol) mit ${ }^{14} \mathrm{C}$-Methode altersbestimmt. Zeitschrift für Gletscherkunde und Glazialgeologie, 9: 329-330.

Kohl, C. P. \& Nishizumi, K. (1992): Chemical isolation of quartz for measurement of in-situ-produced cosmogenic nuclides. - Geochimica et Cosmochimica Acta, 56: 3583-3587.

Kubik, P.W. \& Reuther, A.U. (2007): Attenuation of cosmogenic ${ }^{10}$ Be production in the first $20 \mathrm{~cm}$ below a rock surface. - Nuclear Instruments and Methods in Physical Research, Section B 259: 616-624.

LAJ, C., Kissel, C. \& BeER, J. (2004): High resolution global paleointensity stack since 75 kyr (GLOPIS-75) calibrated to absolute values. - Geophysical Monograph Series, American Geophysical Union, Washington D.C.: $255-265$
LAL, D. (1991): Cosmic ray labeling of erosion surfaces: in situ nuclide production rates and erosion models. - Earth Planetary Science Letters, 104: 424-439.

Landvik, J. Y., Brook, E. J., Gualtieri, L., Raisbeck, G., Salvigsen, O. ש YIOU, F. (2003): Northwest Svalbard during the last glaciation: Ice-free areas existed. - Geology, 31: 905-908.

Licciardi, J. M., Clark, P. U., Brook, E. J., Pierce, K. L., Kurz, M. D., Elmore, D. \& Sharma, P. (2001): Cosmogenic ${ }^{3} \mathrm{He}$ and ${ }^{10} \mathrm{Be}$ chronologies of the late Pinedale northern Yellowstone ice cap, Montana, USA. - Geology, 29: 1095-1098.

MAнr, A. (1998): Lockerbraunerden und periglaziale Hangsedimente im Bayerischen Wald. Untersuchungen zu Paläoumwelt und Geomorphodynamik im Spätglazial und ihrem Einfluß auf die Pedogenese. Regensburger Geographisch Schriften, 30: 326 S.; Regensburg (Institut für Geographie).

Mailänder, R. \& Veit, H. (2001): Periglacial cover-beds on the Swiss Plateau: indicators of soil, climate and landscape evolution during the Late Quaternary. - Catena, 45: 251-272.

MAnske, D. (1989): Zur eiszeitlichen Überprägung des Arbergebietes, Bayerischer Wald. - Acta Albertina Ratisbonensia, 26: 183-198.

Martinson, D. G., Pisias, N. G., Hays, J. D., Imbrie, J., Moore, T. C. \& Shackleton, N. J. (1987): Age Dating and the Orbital Theory of the Ice Ages: Development of a High-Resolution 0 to 300,000-Year Chronostratigraphy. - Quaternary Research, 27: 1-29.

Menzies, J. \& Habbe, K. A. (1992): A cryogenic wedge within gravels, north of Kempten, Bavaria, F.R.G. - Zeitschrift für Geomorphologie NF, 36: 365-374.

Meyer, R. K. F. \& Schmidt-Kaler, H. (1997): Auf den Spuren der Eiszeit südlich von München, westlicher Teil. - Wanderungen in die Erdgeschichte 9. München: $126 \mathrm{~S}$.

MüLlER-Hohenstein, K. (1973): Die naturräumlichen Einheiten auf Blat 165/166 Cham. - In: Bundesforschungsanstalt für Landeskunde und Raumordnung (ed.): Naturräumliche Gliederung Deutschlands. Geographische Landesaufnahme 1:200,000. Bonn, $86 \mathrm{~S}$.

Ochs, M. \& Ivy-Ochs, S. (1997): The chemical behaviour of $\mathrm{Be}, \mathrm{Al}, \mathrm{Fe}$ $\mathrm{Ca}$, and $\mathrm{Mg}$, during AMS target preparation from terrestrial silicates modeled with chemical speciation calculations. - Nuclear Instruments and Methods in Physical Research, Section B 123: 235-240.

OegGL, K. (1992): Sediment- und Makrofossilanalysen aus dem Lanser See in Tirol, Österreich. Ein Beitrag zur spätglazialen Bio- und Chronostratigraphie der Ostalpen. - Flora, 186: 317-339.

OTT, W. D. \& Rohrmüller, J. (1998): Geologische Karte von Bayern 1:25 000 Blatt 6944 Bodenmais. - München (Bayerisches Geologisches Landesamt).

Owen, L. A., Finkel, R. C., Minnich, R. A. ש Perez, A. E. (2003): Extreme southwestern margin of late Quaternary glaciation in North America: Timing and controls. - Geology, 31: 729-732.

Owen, L. A., Gualteri, L., Finkel, R. C., Caffee, M. W., Benn, D. I. \& ShARMA, M. C. (2001): Cosmogenic radionuclide dating of glacial landforms in the Lahul Himalaya, northern India: defining the timing of Late Quaternary glaciation. - Journal of Quaternary Science, 16: $555-563$.

Partsch, J. (1882): Die Gletscher der Vorzeit in den Karpathen und den Mittelgebirgen Deutschlands. - 198 S.; Breslau (Koebner).

Penck, A. \& BRÜCKNER, E. (1901/09): Die Alpen im Eiszeitalter. - 1199 S. Leipzig (Tauchnitz).

Penck, A. (1882): Die Vergletscherung der deutschen Alpen, ihre Ursachen, periodische Wiederkehr und ihr Einfluß auf die Bodengestaltung. - 484 S.; Leipzig (Barth).

Penck, A., Böhm, A. \& Rodler, A. (1887): Bericht über eine gemeinsame Excursion in den Böhmerwald. - Zeitschrift der Deutschen Geologischen Gesellschaft, 39: 68-77.

PfAffl, F. (1988): Glazialmorphologische Untersuchungen am RachelNordkar und am Großen Arbersee im Bayerischen Wald. - Geologische Blätter Nordost Bayerns, 38: 7-26.

Pfaffl, F. (1989): Der Bayerische Wald im Tertiär und Quartär. - Geologische Blätter Nordost Bayerns, 39: 1-38.

Pfaffl, F. (1997): Zur Geologie des Arbergebietes. - In: Bayerisches Landesamt für Umweltschutz (ed.): Die Naturschutzgebiete am Arber. Schriftenreihe: Aus den Naturschutzgebieten Bayerns, 144: 9-14; München.

Pfaffl, F. (2001): Vor 30.000 Jahren: Gletscher am Arber. - Schöner Bayerischer Wald, 141: 35.

Phillips, F. M., Zreda, M. G., Smith, S. S., Elmore, D., KubiK, P. W. ש Sharma, P. (1990): A cosmogenic chlorine-36 chronology for glacial deposits at Bloody Canyon, Eastern Sierra Nevada. - Science, 248: $1529-1532$. 
Preusser, F. (2004): Towards a chronology of the Late Pleistocene in the northern Alpine Foreland. - Boreas, 33: 195-210.

Priehäusser, G. (1927): Der Bayerische Wald im Eiszeitalter. I. Glaziale Spuren in der Umgebung des Großen Arbersees. - Geognostische Jahrhefte, 40: 133-150.

Priehäusser, G. (1930): Die Eiszeit im Bayerischen Wald. - Abhandlungen der Geologischen Landesuntersuchung des bayerischen Oberbergamtes München: 5-47.

Putkonen, J. \& O’Neal, M. (2006): Degradation of unconsolidated Quaternary landforms in the western North America. - Geomorphology, 75: 408-419.

Putkonen, J. \& Swanson, T. (2003): Accuracy of cosmogenic ages for moraines. - Quaternary Research, 59: 255-261.

RAAB, T. (1999): Würmzeitliche Vergletscherung des Bayerischen Waldes im Arbergebiet. - Regensburger Geographische Schriften, 32: 327 S.; Regensburg (Institut für Geographie).

RAAB, T. \& VöLKEL, J. (2003): Late Pleistocene glaciation of the Kleiner Arbersee area in the Bavarian Forest, south Germany. - Quaternary Science Reviews, 22: 581-593.

Rathjens, C. (1985): Erläuterungen zur Geomorphologischen Karte 1:100 000 der Bundesrepublik Deutschland. GMK 100 Blatt 3, C8338 Rosenheim. GMK Schwerpunktprogramm: 69 S. + map; Stuttgart (GeoCenter).

RAthsburg, A. von (1928): Die Gletscher des Böhmerwaldes zur Eiszeit. - Berichte der Naturwissenschaftlichen Gesellschaft Chemnitz, 22: 65-161.

Rathsburg, A. von (1930): Neue Beiträge zur Vergletscherung des Böhmerwaldes während der Eiszeit. - Mitteilungen des Vereins für Erdkunde, Dresden, $106 \mathrm{~S}$.

Reimer, P. J., Baillie, M. G. L., Bard, E., Bayliss, A., Beck, J. W., Blackwell, P. G., Bronk Ramsey, C., Buck, C. E., Burr, G. S., Edwards, R. L., Friedrich, M., Grootes, P. M., Guilderson, T. P., Hajdas, I., Heaton, T. J., Hogg, A. G., Hughen, K. A., Kaiser, K. F., Kromer, B., McCormac, F. G., Manning, S. W., Reimer, R. W., Richards, D. A., Southon, J. R., Talamo, S., Turney, C. S. M., van Der Plicht, J., \& WeyHENMEYER, C. E. (2009). IntCal09 and Marine09 radiocarbon age calibration curves, 0-50,000 years cal BP. - Radiocarbon, 51(4): 1111-1150.

Reinecker, J. \& Lenhardt, W. A. (1999): Present-day stress field and deformation in eastern Austria. - International Journal of Earth Sciences, 88: $532-550$.

ReITNER, J. M. (2005): Quartärgeologie und Landschaftsentwicklung im Raum Kitzbühel - St. Johann i. T. Hopfgarten (Nordtirol) vom Riss bis in das Würm-Spätglazial (MIS 6-2). - Dissertation Univ. Wien, 190 S.

ReITNER, J. M. (2007): Glacial dynamics at the beginning of Termination in the Eastern Alps and its stratigraphic implications. - Quaternary International, 164/165: 64-84.

Reuther, A. U. (2007): Surface exposure dating of glacial deposits from the last glacial cycle. Evidence from the Eastern Alps, the Bavarian Forest, the Southern Carpathians and the Altai Mountains. - Relief Boden - Paläoklima, 21, Schweizerbart, Stuttgart, 213 S. + Appendix A - E.

Reuther, A. U., Ivy-Ochs, S. \& Heine, K. (2006): Application of surface exposure dating in glacial geomorphology and the interpretation of moraine ages. - Zeitschrift für Geomorphologie NF, Suppl.-Vol. 142 335-359.

Rinterknecht, V. R., Clark, P. U., Raisbeck, G. M., Yiou, F., Bitinas, A., Brook, E. J., Marks, L., Zelčs, V., Lunkka, J.-P., Pavlovskaya, I. E., Piotrowski, J. A. \& Raukas, A. (2006): The Last Deglaciation of the Southeastern Sector of the Scandinavian Ice Sheet. - Science, 311: 1449-1452 (and supporting online material).

Rother, K. (1995): Die eiszeitliche Vergletscherung der deutschen Mittelgebirge im Spiegel neuerer Forschungen. - Petermanns Geographische Mitteilungen, 139: 45-52.

Rothpletz, A. (1917): Die Osterseen und der Isar-Vorlandgletscher. - Mitteilungen der Geographischen Gesellschaft München, 12: 99-298.

Scheuerer, M. (1997): Das Klima des Arbergebietes. - In: Bayerisches Landesamt für Umweltschutz (ed.): Die Naturschutzgebiete am Arber. - Schriftenreihe: Aus den Naturschutzgebieten Bayerns, München, 144: 15-17.
Schmeids, H. (1971): Ein Beitrag zur spätglazialen Vegetations- und Waldentwicklung im westlichen Salzachgletschergebiet. - Eiszeitalter und Gegenwart, 22: 110-126.

Schozneich, P. (1998) : Corrélation du dernier maximum glaciaire et de la déglaciation alpine avec l'enregistrement isotopique du Groenland. - Bulletin d'Association Française d'Étude Quaternaire, 9: 203-215.

Semmel, A. (1973): Periglaziale Umlagerungszonen auf Moränen und Schotterterrassen der letzten Eiszeit im deutschen Alpenvorland. Zeitschrift für Geomorphologie NF, Suppl.-Vol. 17: 118-132.

Seret, G., Dricot, E. \& WANSARD, G. (1990): Evidence for an early glacial maximum in the French Vosges during the last glacial cycle. - Nature, 346: 453-456.

Stone, J. O. (2000): Air pressure and cosmogenic isotope production. Journal of Geophysical Research, 105 B10: 23753-23760.

SutER, J. (1981): Gletschergeschichte des Oberengadins: Untersuchung von Gletscherschwankungen in der Err-Julier-Gruppe. - Physische Geographie Universität Zürich, 2: 147 S.

Synal, H.-A., Bonani, G., Döbeli, M., Ender, R. M., Gartenmann, P., Kubik, P. W., Schnabel, C. \& Suter M. (1997): Status report of the PSI/ETH AMS facility. - Nuclear Instruments and Methods in Physical Research, B123: 62-68.

Troll, C. (1924): Der diluviale Inn-Chiemsee-Gletscher. - 121 S.; Stuttgart (Engelhorn).

Troll, C. (1925): Die Rückzugsstadien der Würmeiszeit im nördlichen Vorland der Alpen. - Mitteilungen der Geographischen Gesellschaft München, 18: 281-292.

Troll, C. (1937): Die jungeiszeitlichen Ablagerungen des Loisachvorlandes in Oberbayern. - Geologische Rundschau, 28: 599-611.

Troll, C. (1957): Tiefenerosion, Seitenerosion und Akkumulation der Flüsse im fluvioglazialen und periglazialen Bereich. - Petermanns Geographische Mitteilungen, Ergänzungsheft 262 (Machatschek-Festschrift): 213-226.

Troll, G. (1967a): Bau und Bildungsgeschichte des Bayerischen Waldes. In: Bayerisches Geologisches Landesamt (ed.): Führer zu geologischpetrographischen Exkursion im Bayerischen Wald. - Geologica Bavarica, 58: 15-33.

Troll, G. (1967b): Der Arber-Kaitersberg Zug. - In: Bayerisches Geologisches Landesamt (ed.): Führer zu geologisch-petrographischen Exkursion im Bayerischen Wald. - Geologica Bavarica, 58: 53-66.

Van Husen, D. (1977): Zur Fazies und Stratigraphie der jungpleistozänen Ablagerungen im Trauntal. - Jahrbuch der Geologischen Bundesanstalt, Austria, 120: 1-130.

VAN HusEn, D. (1987): Die Ostalpen in den Eiszeiten. - 24 S. + 1 map; Wien (Geologische Bundesanstalt).

VAn Husen, D. (1997): LGM and Late-Glacial fluctuations in the Eastern Alps. - Quaternary International, 38/39: 109-118.

VAN Husen, D. (2000): Geological processes during the Quaternary. - Mitteilungen der Österreichischen Geologischen Gesellschaft, 92: 135-156.

VAN HusEn, D. (2004): Quaternary glaciations in Austria. - In: EHLERs, J. \& GibBARD, P. L. (eds.): Quaternary Glaciations - Extent and Chronology, Part I: 1-13; Amsterdam (Elsevier).

VÁzQuez-SElEm, L. ひ HeInE, K. (2004): Late Quaternary Glaciation of Mexico. - In: Ehlers, J. \& GibBard, P. L. (eds.): Quaternary Glaciations Extent and Chronology, Part III: 233-242; Amsterdam (Elsevier).

Von Grafenstein, U., Erlenkeuser, H., Brauer, A., Jouzel, J. \& Johnson, S. J. (1999): A mid-European decadal isotope-climate record from 15,500 to 5,000 years BP. - Science, 284: 1654-1657.

Zech, R., Glaser, B., Sosin, P., Kubik, P.W. \& Zech, W. (2005): Evidence for long-lasting landform surface instability on hummocky moraines in the Pamir Mountains, Tajikistan) from ${ }^{10} \mathrm{Be}$ surface exposure dating. - Earth and Planetary Science Letters, 237: 453-461.

Zehendner, M. (1986): Der Wald. - In: Fetzer, K. D. et al. (eds.): Standortliche Bodenkarte von Bayern 1: 50.000, München-Augburg und Umgebung: 91-100; München (Geologisches Landesamt).

ZRedA, M. \& Phillips, F. M. (1995): Insights into alpine moraine development from cosmogenic ${ }^{36} \mathrm{Cl}$ buildup dating. - Geomorphology, 14 149-156.

Zreda, M., Phillips, F. M. \& Elmore, D. (1994): Cosmogenic ${ }^{36} \mathrm{Cl}$ accumulation in unstable landforms. 2. Simulations and measurements on eroding moraines. - Water Resources Research, 30: 3127-3136. 


\section{Appendix}

\section{Erosion rates}

\section{Erosion rate determination in the study area Bavarian} Forest

The local erosion rate of the cordierite-sillimanite gneiss in the study area of the Bavarian Forest was calculated from the measured nuclide concentrations at two different sites.

Protruding quartz veins along the vertical bedrock cliffs on the western catchment side are rounded at the sides and show striation in the direction of the former glacier flow. In order to confirm the glacial origin of these striae, instead of originating processes related to faulting of the jointed gneissic bedrock, a bedrock piece was investigated for recrystallization of minerals such as calcites typically found on fault-polish (Harnisch). No such forms were recognized (M. Keller, pers. comm. 2003), indicating that the quartz veins were actually glacially polished. Geomorphological field descriptions had already suggested a glacial origin of the striations (RATHSBURG 1928, 1930). A minimum erosion rate of $3.1 \mathrm{~mm} \mathrm{ka}^{-1}$ can be calculated from the surface relief of the protruding glacially polished quartz veins on the vertical cliff south of the lake (4.5 cm, KAS-1-1, 2-1, 3-1) and its

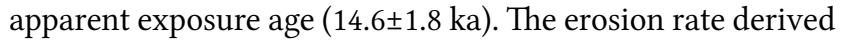
from the quartz veins in a steep wall is interpreted as a minimum erosion rate because the vertical wall has never been covered by organic material. Most of the other boulders in the study area, however, are covered by a humus-soil layer of varying thickness (see Fig. 2 main text). Surface weathering in the gneiss surfaces is considerably enhanced under the organic cover. Surfaces covered with soil showed loose chips of rock on the surface and the rock was more deeply weathered.

The relatively high nuclide concentration from a sampled surface on the Arber summit (BW-04-01) can be interpreted either as a minimum exposure age (98.4 ka, weighted mean of two measurements) when calculated without erosion, or as a maximum erosion rate. A maximum erosion rate is calculated if it is can be assumed that the nuclide concentration has reached a secular equilibrium state in which surface erosion and radioactive decay balances the production of nuclides in the surface. This allows one to solve the production equation for the long-term erosion rate of the bedrock. The high nuclide concentration in sample BW-04-01 may be indicative of the sample having reached secular equilibrium. The measured concentrations indicate an erosion rate of $5.7 \mathrm{~mm} \mathrm{ka}^{-1}$ (weighted mean of the two measurements). This erosion rate constitutes a maximum erosion rate because a higher erosion rate would require the nuclide concentration in the surface to be lower. If the steady-state had not yet been reached, the calculated erosion rate would be too high.

As described above, a minimum erosion rate of $3.1 \mathrm{~mm}$ $\mathrm{ka}^{-1}$ and a maximum erosion rate of $5.7 \mathrm{~mm} \mathrm{ka}^{-1}$ were derived in the study areas. Ivy-OcHs et al. (2006b) calculated a similar erosion rate from a weakly foliated granitic boulder in Switzerland ( $\left.5.5 \mathrm{~mm} \mathrm{ka}^{-1}\right)$.

An erosion rate of $5 \pm 2 \mathrm{~mm} \mathrm{ka}^{-1}$ was assumed as a best estimate of the long-term erosion rate in the study area based on the calculated maximum and the minimum erosion rate.

\section{Erosion rate determination in the study area Northern Alpine Foreland}

Erosion of the surface of the boulders could be roughly estimated at boulder AVS-03-01, where a quartz vein was protruding approximately $5 \mathrm{~cm}$ above the rest of the surface. The quartz vein itself was not polished but had a rough surface, indicating that it is not the original surface. If an exposure age of the boulder of $16.5 \mathrm{ka}$ is assumed, this surface relief suggests a minimum erosion rate of $3 \mathrm{~mm} \mathrm{ka}^{-1}$. Measurements of surface erosion rates in the Western Alps yield values of $3 \mathrm{~mm} \mathrm{ka}^{-1}$ for a weakly-foliated hornblende granite at Solothurn from relief differences (IvY-Ochs et al. 2004) and $5.5 \mathrm{~mm} \mathrm{ka}^{-1}$ for a granitic boulder (Mont Blanc granite) at Montoz based on a saturation assumption (Ivy-OcHs et al. 2006b). In this study, an erosion rate of $5.5 \pm 2.5 \mathrm{~mm} \mathrm{ka}^{-1}$ is used as an estimate for the age calculations. 